\section{A- ARS BILDUMA ISSN 1989-9262 UPV/EHU Press} ARSBILDUMA (CC BY-NC-ND 4.0)

https://doi.org/10.1387/ars-bilduma.21321 BIBLID [(2020), 10;153-170]

Recibido: 16/09/2019 Aceptado: 27/11/2019

\section{RAMÓN RAMOS ALFONSO}

Archivo-Biblioteca de Marchena

C/Doctor Diego Sánchez, 17

41620 Marchena (Sevilla)

bibliotecademarchena@gmail.com

https://orcid.org/0000-0002-7526-6079

\section{MANUEL ANTONIO RAMOS SUÁREZ}

Universidad de Sevilla

Facultad de Bellas Artes

C/ Laraña, 3

41003 Sevilla (Sevilla)

mantonioramos@us.es

https://orcid.org/0000-0001-8397-6532

\title{
SALVADOR AZPIAZU Y JOSÉ GESTOSO EN LA ILUSTRACIÓN ARTÍSTICA. RELACIONES PERSONALES Y PROFESIONALES
}

\author{
SALVADOR AZPIAZU AND JOSÉ GESTOSO IN THE ARTISTIC ILLUSTRATION. \\ PERSONAL AND PROFESSIONAL RELATIONSHIPS
}

SALVADOR AZPIAZU E JOSÉ GESTOSO DANS L'ILLUSTRATION ARTISTIQUE.
RELATIONS PERSONNELLES ET PROFESSIONNELLES

RESUMEN

En este artículo se analizan los trabajos realizados por el ilustrador Salvador Azpiazu junto con el escritor sevillano José Gestoso en La Ilustración Artística, revista de crónicas de fines del siglo XIX. Gracias a la correspondencia conservada, así como a la documentación contable de la editorial barcelonesa Montaner y Simón se pueden establecer relaciones personales y profesionales entre ambos.

\section{PALABRAS CLAVE}

Salvador Román Azpiazu Imbert; José Gestoso Pérez; La Ilustración Artística; ilustración; tradiciones; Vitoria; Sevilla; fotodocumentalismo.

\section{ABSTRACT}

This article analyzes the work done by the illustrator Salvador Azpiazu together with the Sevillian writer José Gestoso in The Artistic Illustration, magazine of chronicles of the late nineteenth century. Thanks to the correspondence preserved, as well as the accounting documentation of the Barcelona publisher Montaner and Simón, personal and professional relationships can be established between them.

\section{KEYWORDS}

Salvador Román Azpiazu Imbert; José Gestoso Pérez; The Artistic Illustration; illustration; traditions; Vitoria; Seville; photodocumentalism.
RÉSUMÉ

Cet article analyse le travail de l'illustrateur Salvador Azpiazu avec lécrivain sévillan José Gestoso dans L'illustration artistique, magazine de chroniques de la fin du XIXe siècle. Grâce à la correspondance conservée et à la documentation comptable des éditeurs barcelonais Montaner et Simón, des relations personnelles et professionnelles peuvent être établies entre eux.

\section{MOTS-CLÉS}

Salvador Román Azpiazu Imbert; José Gestoso Pérez; L'illustration artistique; illustration; traditions; Vitoria; Séville; photodocumentalisme. 


\section{INTRODUCCIÓN}

Hasta hace unos años se conocía muy poco sobre la vida de Salvador Román Azpiazu Imbert, incluso a pesar de ser un artista del que se conservan numerosas obras en el Museo de Bellas Artes de Álava'. Las publicaciones que trataban sobre su vida y obra eran muy reducidas, así como los datos que conformaban su biografía, si bien se han podido aportar nuevas noticias recientemente

Salvador Román Azpiazu Imbert nació el 9 de agosto de 1867 en la calle Postas de la ciudad de Vitoria, bautizándose dos días después en la parroquia de san Miguel Arcángel de la ciudad. Su padre fue Joaquín Azpiazu, natural de Logroño y procurador de profesión y su madre Daría Imbert, natural de Vitoria, que llegó a ser la primera profesora de dibujo de la Academia de Bellas Artes de esa provincia. Fueron sus abuelos paternos José Francisco Azpiazu, de Segura (Gipuzkoa) y Ceferina Saenz de Calahorra. Y sus abuelos maternos Carlos Imbert de Albi (Francia) y de profesión escultor y Cándida Aranguren de Abornikano (Álava). Salvador fue el mayor de tres hermanos, José María y Ramón ${ }^{3}$.

También se sabe muy poco de su infancia y juventud, y aunque unos biógrafos apuntan que vivió en Barcelona con su madre y hermanos ${ }^{4}$ y otros afirman que vivieron en Madrid $^{5}$, hoy se puede afirmar que Salvador Azpiazu vivió en Álava durante los años 1877 hasta 1882. Aprobó los estudios de primera enseñanza en octubre de 1877 tras la realización

1 En el catálogo online del museo se recogen un total de novecientas noventa y cinco resultados con tantas obras realizadas en acuarela, grafito. De ellos, novecientos noventa y dos son dibujos, dos pinturas y una fotografía. https://apps.euskadi.eus/v09aNucleoWar/ciucFVerListaDispatch.do;jsessionid=yPj0hyC6s7DCFgnebpWsS3ARQbsgxdOwxtqQBORBIsmTt2BZhrtn!-31259074 (consultado 26/5/2019).

2 Entre los trabajos que tratan algunos aspectos vitales están: GONZÁLEZ DE ASPURU, S.: Salvador de Azpiazu. Itinerarios y figuras de un artista alavés. [Exposición] Álava, Museo de Bellas Artes, 2005 VVAA.: "Archivo Municipal de Vitoria-Gasteiz. Sección de Fotografía: Fondo Azpiazu. París: Fin de siglo", Colección Photo-album Bilduma, n. ${ }^{\circ} 11$. Zarautz, Photomuseum, 1997 y "París: Fin de siglo. Salvador Azpiazu” en Revista digital Photo Berriak, n. ${ }^{\circ}$ 2. Zarautz, Photomuseum, 2010, pp. 5-45. Recientemente se ha publicado una obra que recoge nuevos datos sobre su vida y obra, vid. RAMOS ALFON SO, R.; RAMOS SUÁREZ, M. A.: Azpiazu y Marchena. Imágenes de una villa entre siglos. Marchena,

3 Ibid., p. 13

4 Vid. GONZÁLEZ DE ASPURU, S.: op. cit., p. 3.

5 Vid. http://aunamendi.eusko-ikaskuntza.eus/es/azpiazu-imbert-salvador/ar-17352/ (consultado el 15/6/2019) de un examen. Posteriormente cursó estudios de secundaria en el Instituto de Vitoria en asignaturas como latín, castellano, aritmética, álgebra, geografía, historia universal, retórica y poética, entre otras. Sus calificaciones fueron de notable y aprobado. Durante el curso 1881-1882 el estudiante se domicilió en la calle Arquillos, núm. 6 de esa ciudad e hizo traslado de matrícula al Instituto Cardenal Cisneros situado en Madrid ${ }^{6}$.

Para marzo de 1885 ya vivía como estudiante en Madrid, concluyendo su carrera de perito agrícola en el Instituto Agrícola de Alfonso XII al año siguiente y solicitando en agosto de 1888 su primer destino en las ciudades de Madrid, Barcelona o Toledo ${ }^{7}$. Gracias a su cuaderno de dibujos se sabe que entre los años 1889 y 1890 fue destinado a ciudades de la provincia de Gerona como Lloret, Tossa, Jafre, Hostalrich, Besalú, Figueras y Llansa. Los años 1890 a 1893 trabajó en Madrid y Toledo, los años 1894 a 1896 se trasladó a París. Entre los años 1897 y 1899 estuvo en Sevilla y provincia trabajando en Marchena, Lora del Río, Osuna... entre otros. También ese último año estuvo en Ciudad Real. Los años 1900 y 1901 los pasó nuevamente en Toledo y París. El año 1903 se encontraba en Barcelona y en 1905 en la provincia de Tarragona. El año 1906 lo pasó entre Madrid, Sevilla, Toledo y Zamora. El año 1907 estuvo en Calahorra y San Juan de la Luz. En el año 1910 estuvo en numerosas ciudades como Barcelona, Burgos, Cenicero, Guadamur, Madrid, Miranda de Ebro, Nájera, Santo Domingo de la Calzada, Toledo, así como Italia. El año 1911 estuvo en Getafe, el de 1912 en Almodóvar del Campo, Castellón, Zaragoza y Barcelona. El año 1913 estuvo en Barcelona, Castellón y Zaragoza. En el año 1914 trabajó en Zaragoza, Huesca, Logroño, Viana y Laguardia, para en el año 1915 pasar por la Alcudia, Almodóvar del Campo Madrid y pueblos de Sevilla como Marchena y Utrera. El año 1916 estuvo en Almodóvar del Campo, en el año 1918 se encontraba en Teruel, Tortosa y Tarragona. El año 1920 pasó por Plasencia, Astorga, Orense y Tuy. El año 1923 estuvo en Sigüenza, Tarazona y Soria. Falleció el 5 de enero de 1927 en la ciudad de Madrid de forma repentina ${ }^{8}$.

Entre las muchas ocupaciones que Azpiazu tuvo como topógrafo destacó el levantamiento de un catastro por masas de cultivo y clases de terreno planteado tras la aparición de una nueva ley de rectificación de amillaramiento. Tras su puesta en funcionamiento en Francia se implantó de forma experimental en Granada para posteriormente extenderse a

6 Cfr. ARCHIVO GENERAL DE LA COMUNIDAD AUTÓNOMA DEL PAís VASCO. Expedientes de alumnos. IES. Ramiro de Maeztu BHI. Vitoria-Gasteiz. Expediente de Salvador Aspiazu Imbert. Vid. RAMOS ALFONSO, R.; RAMOS SUÁREZ, M. A.: op. cit., p. 14 Ibid., p. 18. 
Cádiz, Córdoba, Málaga y Sevilla. Este trabajo fue realizado por el Instituto Geográfico y Estadístico?. Y aunque su profesión era perito agrícola, dedicó gran parte de su tiempo libre a la realización de fotografías, dibujos e ilustraciones para numerosas ediciones de libros y revistas de tirada nacional y extranjera. Su trabajo como fotógrafo fue complementario a sus tareas para elaborar el catastro. Conocía la técnica fotográfica y utilizaba la fotografía no para hacer un reportaje de los edificios existentes en las ciudades, sino para captar la vida, los lugares y su actividad siendo la figura humana primordial para entender e interpretar esos espacios ${ }^{10}$. Azpiazu también realizó numerosas pinturas y dibujos como lo demuestran las conservadas en el Museo de Bellas Artes de Álava. Según se deduce de La Ilustración Artística, tras sus primeros estudios de arte y trasladarse a París tuvo como maestro a Daniel Urrabieta Vierge ${ }^{11}$. Es de suponer que en esos primeros estudios contó con la ayuda de su madre Daría Imbert, hija del polifacético artista francés Carlos Imbert de Albi, la cual incluso dio clases de dibujo a niñas en la Academia de Bellas Artes de Vitoria ${ }^{12}$. Fueron numerosos los dibujos que realizó Azpiazu para ilustrar novelas como $E$ Calvario de Francisco Acebal ${ }^{13}$, u otros libros como La Bendita Tierra de Serafín y Joaquín Álvarez Quintero con numerosas vistas arquitectónicas de ciudades y pueblos de España ${ }^{14}$. También trabajó como ilustrador conociéndose sus trabajos en los rotativos $L^{\prime}$ Univers Illustré y La Esquella de la Torratxa después del año $1894^{15}$.

Se sabe que Salvador Azpiazu inició sus trabajos para los editores Montaner y Simón en la revista la Ilustración Artística ilustrando distintas crónicas sobre la ciudad de París. Con lo textos escritos por Juan B. Enseñat iniciaron una sección denominada Crónicas parisienses que se publicaron desde el año 1894 hasta el año 1899. Con ellas no pretendían descubrir nada de la gran ciudad, sino ofrecer "las impresiones que su agitada vida produce en nuestra alma", mostrando la vida parisina no solo con el texto, sino también mostrando la imagen de esa vida a través del dibujo del artista ${ }^{16}$. La primera crónica apareció en la revista de primero de octubre de 1894 mostrando cuatro dibujos sobre las maniobras militares de fortaleza en

Ibid., p. 20

10 Vid. París... s/p.

11 Vid. RAMOS ALFONSO, R.; RAMOS SUÁREZ, M. A.: op. cit., p. 22

1 Cfr. VIVES CASAS, F.: La Academia de Bellas Artes de Vitoria (1818-1889). Vitoria, Ayuntamiento, 2000, p. 191.

3 Editada en Barcelona por Montaner y Simón en el año 1905.

14 Editada en Madrid en la editorial Voluntad en el año 1927.

15 Vid. RAMOS ALFONSO, R.; RAMOS SUÁREZ, M. A.: op. cit., p. 27, 31

16 Ibid., p. 31 los alrededores de París ${ }^{17}$. A esa siguió otra titulada Aspectos de París a la muerte del zar de Rusia, otra sobre jardines parisinos ${ }^{18}$ y la Navidad en París ${ }^{19}$. A continuación realizaron una crónica sobre bulevares parisinos ${ }^{20}$. En esas ilustraciones ya se apreciaba la forma de trabajar del dibujante. Azpiazu hacía fotografías que posteriormente pasaba al dibujo, bien como una copia literal o utilizando detalles de varias para hacer composiciones (Figs. 1 y 2). Otras como la llegada del frío a París, la muerte de Can Robert y llegada de Rochefort ${ }^{21}$, el patinaje artístico sobre ruedas y las fiestas populares en París ${ }^{22}$. En mayo y junio de 1895 ofrecieron crónicas sobre una exposición anual de pinturas, así como teatros conciertos y café cantantes parisinos, y el gran prix de París ${ }^{23}$. Los meses de julio a octubre de ese año también se ofrecieron crónicas parisinas en la revista tratándose temas como el Chat Noir y su escuela, deportes y racing-club, el Canotage de París y el domingo en los alrededore de París ${ }^{24}$. En los años 1896 y 1897 ilustró siete nuevos reportajes parisinos escritos por J. B Enseñat y tratando los cafés del boulevard de París, sport aristocrático, la miseria en París, el barrio latino de París, tres etapas, bailes excéntricos y el Moulin Rouge ${ }^{25}$.

También ilustró durante varias semanas la publicación de la novela Abandonada escrita por Enrique Greville ${ }^{26}$. Entre las imágenes destacan: una de gran tamaño en la que una joven lee un libro a un niño acompañada por un perro en un jardín, un cartero entregando una carta a una mujer en la puerta de una casa, una señora bajándose de un carruaje, y

17 Se ha podido conocer que Azpiazu cobró 30 pesetas por esa crónica, pues se conservan los libros contables de la empresa editora Montaner y Simón. Cfr. ARCHIVO DEL MUSEU DEL DISSENY DE BARCELONA (desde ahora AMDB.) Fondo Editorial Montaner y Simón (desde ahora, FEMS.) Contabilidad General. Libro de Diario, n. ${ }^{\circ}$ 7, p. 417. Pago efectuado el 5 de octubre de 1894.

18 Esta crónica apareció en La Ilustración Artística, n ${ }^{\circ} 678$ y fechada el 24 de diciembre de 1894

19 Esta apareció en el n. ${ }^{\circ} 680$ de la mencionada revista, pagándose 50 pesetas por los dibujos de ambas crónicas, vid. AMDB. FEMS. Contabilidad General. Libro de Diario, n. ${ }^{\circ}$ 7, p. 511. También se recoge el pago de 160 pesetas a Juan B. Enseñat por los textos de las cuatro crónicas anteriores, Ibid., p. 519.

20 Ibid., p. 519. La crónica salió el 14 de enero de 1895 en el n..$^{\circ} 681$ de La Ilustración Artística y los editore pagaron 35 pesetas por tres dibujos.

21 Estas crónicas aparecieron en febrero y marzo de 1895 en los numeros 685 y 687 abonando los editores 55 pesetas. Ibid., p. 555. Enseñat cobró 80 pesetas por sus escritos, Ibid., p. 583.

22 Por esas crónicas, Azpiazu cobró 195 pesetas, Ibid., p. 519, 555, 591.

23 Ibid., Libro de Diario, n. ${ }^{\circ} 8$, pp. 17, 30, 45. Azpiazu cobró 200 pesetas por los nueve dibujos de ambas crónicas.

4 Ibid p. 69,97,124 La editorial abonó 150 pesetas al ilustrador

25 Ibid., p. 221, 463 y 552

26 Cfr. La Ilustración Artística, n. ${ }^{\circ} 725$ a 730, de 18 noviembre a 23 de diciembre de 1895 

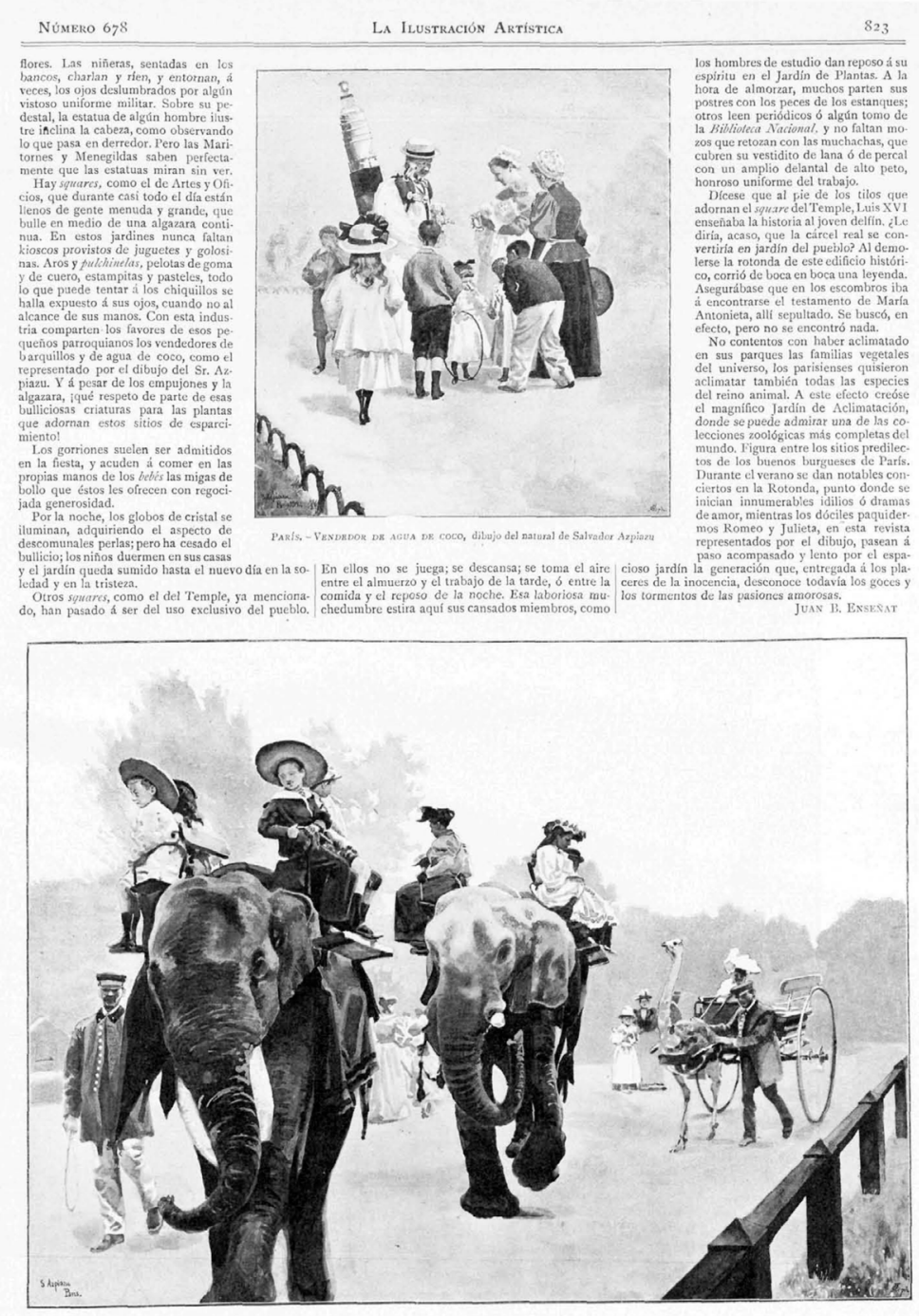

Fig. 1: Romero y Julieta, los dos elefantes del Jardín de aclimatación en “Crónicas parisienses", La Ilustración Artística, n. ${ }^{\circ}$ 678, de 24 de diciembre de 1894, p. 823

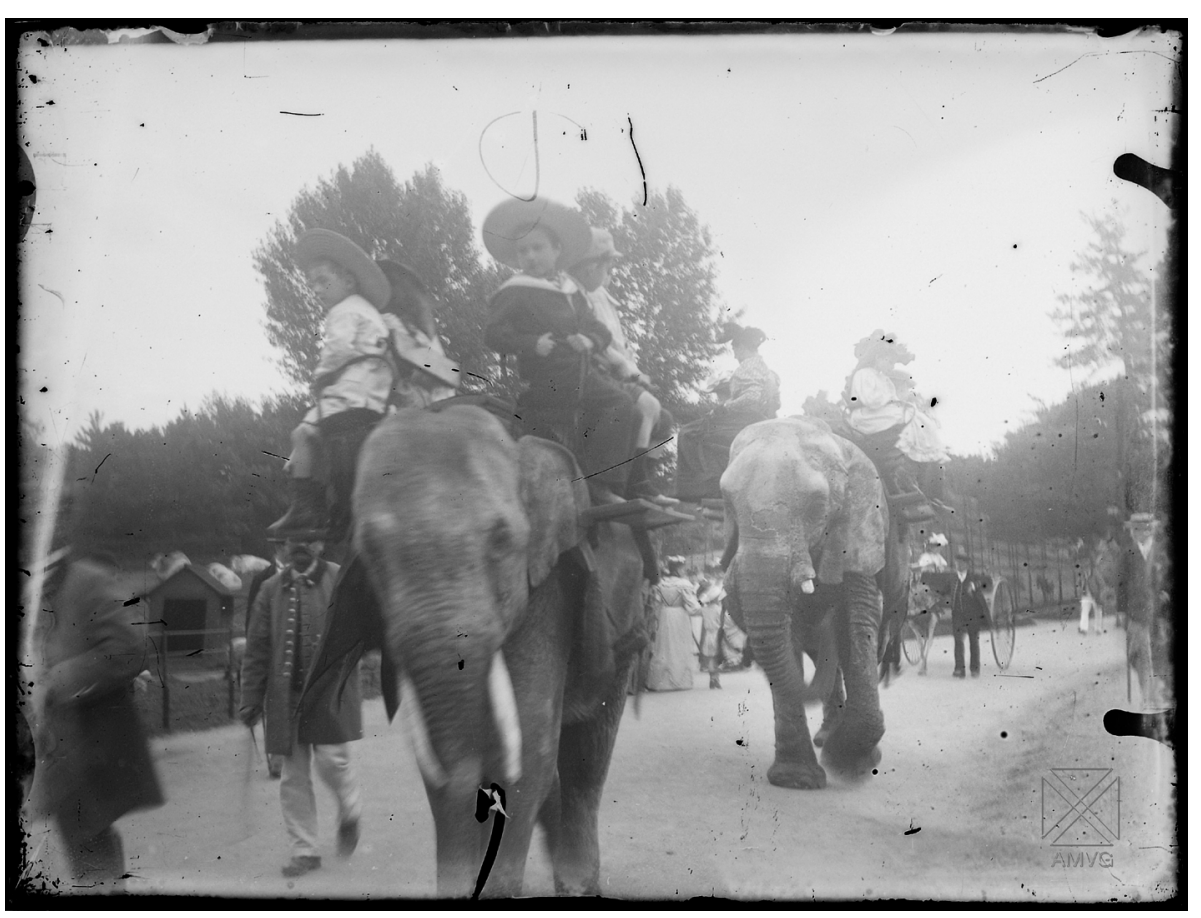

2: Instantánea de dos elefantes en uno de los jardines de París. AMVG. Fondo Azpiazu. AZP-005

otros dibujos menores como una joven leyendo en un jardín, otra señora caminando por la nieve, etc. cuyos paisajes reflejan la ciudad de París por esos años. Para que los dibujos de Azpiazu se pudieran publicar en la revista, debían pasar por las manos de un grabador. En la mayoría de los casos, fue Joseph Tomás el grabador encargado, quien trabajó para la editorial desde el año $1883^{27}$

27 La técnica se mejoró gracias al uso del denominado papel Tom que permitía la sensación de medias tintas que no se podía con el papel ordinario, y se reproducían dibujos que habían sido trazados en negro sobre un papel blanco recubierto de una finísima retícula. Esa retícula se podía también trabajar por eliminación raspándola para que aparecieran toques de blanco, base del sombreado, vid. FONTBONA, F:: "La ilustración gráfica. Las técnicas fotomecánicas", en El Grabado en España. (Siglos XIX y XX) Summa Artis. Vol. XXXI. Madrid, Espasa Calpe, 2000, pp. 429-44 
De igual modo, José Gestoso redactó individualmente algunas crónicas en la revista. E escritor nació en Sevilla en el año 1852. Tras una infancia sin su madre, que falleció dos años después, realizó con dificultades sus estudios pues eran otros sus intereses, si bien finalmente se licenció en Derecho. Ya en esas fechas se relacionaba con sus profesores en tertulias culturales. En el año 1882 contrajo matrimonio con María Daguerre Dospital con quien tuvo cuatro hijas ${ }^{28}$. Apasionado de la ciudad de Sevilla, su patrimonio y sus costumbres... Fue investigador, historiador del arte, apasionado del coleccionismo, defensor del patrimonio artístico, miembro de numerosas instituciones culturales de España y fuera de ella, asiduo articulista de numerosas publicaciones seriadas y autor de numerosos libros relacionados con la historia del arte sevillano entre los que destacan los tres tomos del Ensayo de un Diccionario de los Artífices que florecieron en Sevilla desde el siglo XIII al XVIII inclusive ${ }^{29}$, o la Historia de los Barros vidriados sevillanos desde sus orígenes hasta nuestros días ${ }^{30}$. Falleció en el año 1917 y está sepultado en el Panteón de sevillanos ilustres.

Ya en octubre de 1894 escribió en la revista sobre la orfebrería sevillana coincidiendo con dibujos de Azpiazu sobre maniobras militares en los alrededores de París, o sobre la Semana Santa de Sevilla en abril de $1895^{33}$, la Giralda de Sevilla en julio de $1895^{33}$, así como sobre un personaje sevillano el capitán Gaspar de Yelves ${ }^{34}$. Por tanto, a ninguno le era desconocida la forma de trabajar y proceder de la empresa editora barcelonesa. Será a partir de la primavera de 1897 cuando se limen asperezas relativas a los encargos de los trabajos antes expuestos y cuando ambos trabajen de forma conjunta y continuadamente para La Ilustración Artística.

La relación de amistad de Salvador Azpiazu con José Gestoso ya ha sido puesta de manifiesto ${ }^{35}$. El análisis de la correspondencia resulta fundamental para analizar la vida de ambos, no solo en el aspecto biográfico, sino también en el profesional. Han llegado hasta

28 Para conocer más sobre su vida y obra, véase CASQUETE DE PRADO SAGRERA, N.: José Gestoso y Sevilla. Biografía de una pasión. Sevilla, Ayuntamiento, 2016.

29 Vid. Ensayo de... Pamplona, Analecta, 2001.

30 Vid. Historia de los barros... Sevilla, Ayuntamiento, 1995. Prólogo de Alfonso Pleguezuelo.

31 Vid. La Ilustración Artística, n. ${ }^{\circ}$ 626, de 1 de octubre de 1894

32 Ibid.,${ }^{\circ}{ }^{\circ} 693$, de 8 de abril de 1895 .

33 Ibid., n. ${ }^{\circ} 705$, de 1 de julio de 1895 y n. ${ }^{\circ} 707$, de 15 de julio de ese año.

34 Ibid., n. ${ }^{\circ} 756$, de 22 de junio de 1896

35 Cfr. CASQUETE DE PRADO SAGRERA, N.: op. cit., p. 447. En este libro también se relacionan lo artículos que Gestoso publicó en La Ilustración Artística, pp. 395-399. nosotros las cartas que envió Azpiazu a Gestoso, si bien no se conservan las respuestas de Gestoso al dibujante. A través de las cartas remitidas se sabe en qué lugar y momento se encontraba Salvador Azpiazu, ya que cambió constantemente de residencia, además de los posibles lazos amistosos y profesionales que pudiesen tener. También se conocen algunas cartas de la relación entre Gestoso y la editorial Montaner y Simón ${ }^{36}$.

Las primeras cartas entre Azpiazu y Gestoso son de principios de abril de 1897 cuando Azpiazu se encontraba realizando los estudios de catastro por masas de cultivo y clases de terreno en la localidad sevillana de Marchena ${ }^{37}$. El ilustrador se dirigió al escritor a través de una carta enviada al Ateneo de Sevilla, pues desconocía dónde vivía en la capital También argumentó que no podía desplazarse pues estaba muy atareado con los trabajos del catastro antes mencionado. En esa primera misiva le manifestó que los editores Montaner y Simón de la ciudad de Barcelona debían haber contactado con él para elaborar unas crónicas sobre distintos temas andaluces. Al parecer, la primera crónica planteada se relacionaría con una fiesta de toros en la que Azpiazu como ilustrador haría tres dibujos o escenas y la siguiente versaría sobre la feria, pudiéndose publicar quincenalmente tal como era intención de los editores. No obstante, y a pesar de exponer estos temas a tratar el ilustrador se puso a disposición de Gestoso como buen conocedor de los asuntos de su tierra y le pidió que respondiese lo más pronto posible. Además le indicó que si podían conocerse personalmente en la próxima feria de Sevilla ${ }^{38}$. La respuesta no se hizo esperar pues a través de una carta enviada desde la dirección de la editorial Montaner y Simón, fechada en Barcelona, el 16 de abril de ese año, los editores informaron a Gestoso que habían recibido una carta donde Azpiazu indicaba que el escritor se había negado a escribir sobre el tema de la tienta hasta que los editores no le encargasen el trabajo, encargo que hacen a partir de entonces, recayendo el diseño del artículo en el ilustrador ${ }^{39}$.

El primer trabajo escrito de Gestoso bajo el título Acoso, derribo y tienta llegó el 23 de mayo a la editorial, que posteriormente contactó con el escritor para que lo redujese, pues era demasiado extenso ${ }^{40}$. Sobre esas fechas, Azpiazu se dirigió a Gestoso informándole que había empezado a hacer los dibujos, un total de tres según las necesidades de los editores.

36 Se conservan cartas entre ambos en el fondo Gestoso de la Biblioteca Capitular y Colombina, Ibid., p. 333. 37 Vid. RAMOS ALFONSO, R.; RAMOS SUÁREZ, M.A.: op. cit., p. 18

38 Vid. INSTITUCIÓN COLOMBINA (desde ahora, IC.) Biblioteca Capitular y Colombina (desde ahora BCC.) Fondo Gestoso. Correspondencia. Leg. 1895-1898. Carta n. 391.

39 Ibid., Carta, n. 393

40 Ibid., Carta, n. ${ }^{\circ}$ 400, fechada en Barcelona a 23 de mayo de 1897. 
Los tres dibujos fueron: un garrochista, el acoso de la res y uno más completo donde en el centro de la dehesa se situaba una carreta llena de mujeres y con piqueros y gente a caballo. No obstante, y aunque lo informaba de los dibujos realizados solicitaba un favor de Gestoso. Le pidió si le podía enviar una fotografía en la que apareciera la duquesa de Alba montada en un célebre toro llamado Platero para enviarla al semanario Le monde illustrét1. En junio de ese año la editorial envió carta a Gestoso indicándole que podría realizar hasta seis crónicas ilustradas por Azpiazu, debiendo contactar con él. Además, la editorial le indicó que no era de peor condición que los dibujantes, posiblemente refiriéndose a las retribuciones que percibiría por su trabajo. Al mes siguiente, los editores escribieron a Gestoso para remitirle su primer artículo incluido dentro de la sección "Costumbres Andaluzas", ilustrado por Azpiazu, indicándole que le pagarían por su publicación. A su vez, le devolvieron su artículo "La Cabeza del rey don Pedro" para que lo redujese a la mitad pues era muy extenso, según el editor Simón. Le manifestó que no se demorase pues ya habían elegido el dibujo que acompañaba a ese artículo histórico ${ }^{43}$. Días después adjuntaron el pago del artículo que finalmente recibió el título de "Acoso, derribo y tienta"44. El artículo salió publicado en el número 810 con fecha 5 de julio de $1897^{45}$. En él Gestoso va describiendo cada una de estas acciones analizando la figura del garrochista. Los tres dibujos que ilustran la escena son: un momento del acoso donde dos garrochistas corren tras un toro en un cerrado siendo observados por otros garrochistas, un típico garrochista con la garrocha en su mano y montado a caballo como principal protagonista y la tercera escena recoge el momento en el que los garrochistas son observados por un grupo de muchachas que presencian la fiest sobre una carreta. Van ataviadas con rosas y claveles en el pelo y envueltas en mantones de Manila cantando y tocando la guitarra, haciendo palmas y disfrutando de la fiesta. Las escenas se relacionan con otras muy parecidas que se conservan en fotografías que hizo el mismo Salvador Azpiazu en la localidad de Marchena (Sevilla) donde se aprecian distintos hombres a caballo y con garrochas ${ }^{46}$. El autor del texto cobró treinta pesetas ${ }^{47}$, mientras que el ilustrador cobró cincuenta pesetas por los tres dibujos, cantidades que con posterioridad se repetirán en cada uno de los trabajos que realizaron ${ }^{48}$

41 Ibid., Carta, n. ${ }^{\circ} 403$, año 1897, s/f. firmada en Marchena (Sevilla).

2 Ibid., Carta, n. 395 , fechada en Barcelona en 15 de junio de 1897.

43 Ibid., Carta, s/n. ${ }^{\circ}$, fechada en Barcelona a 7 de julio de 1897.

44 Ibid., Carta, n. ${ }^{\circ} 396$, fechada en Barcelona a 23 de julio de 1897.

5 Vid. La Ilustración Artística, n. ${ }^{\circ} 810$, pp. 6-7.

46 Vid. ARCHIVO MUNICIPAL VITORIA-GASTEIZ (desde ahora, AMVG.) Fondo Azpiazu (desde ahora, AZP), n. ${ }^{\circ} 889$ a 892

Cfr. AMDB. FEMS. Contabilidad General. Libro de Diario, n. ${ }^{\circ}$ 9, p. 55.

48 Ibid., p. 115
En verano de 1897 iniciaron un nuevo trabajo. Azpiazu dirigió una carta a Gestoso en septiembre de ese año para indicarle que llevaba un mes intentando elaborar los tres dibujos que acompañarían la crónica titulada "La Recolección en Andalucía" . Sin embargo, le indicaba que no tenía modelos de segadores típicos, pues la gente que hacía estas labores venía de las provincias de Granada y Almería y que desde primero de julio no estaban en la localidad donde él residía. Por tanto, le proponía que al estar los editores impacientes esperando nuevas crónicas, fuese Gestoso quien propusiese nuevos temas teniendo en cuenta que el ilustrador debía hacer tres dibujos; uno para la cabecera, otro central y uno final ${ }^{49}$. A partir de entonces se van a sentar las bases para hacer nuevas crónicas periodísticas. Azpiazu agradeció a Gestoso las fotografías enviadas, lo que reflejaba la relación profesional entre ambos a la hora de trabajar nuevos temas, así como el empleo de las fotos para recrear escenas dibujadas. Planteó a Gestoso hacer una crónica que se podía dividir en dos; la primera trataría la feria en un pueblo andaluz mostrando los polichinelas observados en la feria de la localidad de Marchena (Sevilla), teniendo ya realizado un dibujo del exterior de sus casillas con curiosos carteles y empleando las fotografías que le envió Gestoso. Le planteó al escritor que hiciese el retrato de Juan Misa el sevillano y que como última ilustración elaborase un grupo característico de la feria. La segunda parte sería para recoger una corrida de toros, cargadas de originalidad en el pueblo donde se encontraba el ilustrador. Esta parte se podría ampliar con capeas y encerronas, o imágenes de muchachas con mantillas en los balcones de las que tenía ya sacados buenos apuntes o incluso fotografías, así como los aficionados sevillanos a la tauromaquia que acuden a los pueblos. Concluyó su carta exponiendo su posible visita a la feria sevillana de san Miguel donde podría conocerlo, como así fue ${ }^{50}$. Azpiazu envió tres dibujos al editor para acompañar su crónica sobre la feria; el primer dibujo era el exterior de la barraca de Juan Misa el sevillano con su muestra de polichinela, el segundo era el escenario con la figura del personaje y el tercero dibujó a un titirimundi rodeado de gente menuda con un curioso anuncio. De la segunda crónica de la feria, ya tenía concluidos dos dibujos. En el primero mostraba la feria taurina dibujando a varias muchachas con mantilla en un balcón y a unos caballistas tomando una copa delante de una barraca de la feria junto a un grupo de muchachas bailando sevillanas ${ }^{51}$. El primer artículo se publicó en el número 834 de la revista, fechado el 20 de diciembre de 1897 bajo el título "Una feria en un pueblo de Andalucía”, ilustrándose con los dibujos comentados: el montaje de las marionetas con un

49 Vid. IC. BCC. Fondo Gestoso. Correspondencia. Leg. 1895-1898. Carta, n. 241. Carta fechada en Marchena a 13 de septiembre de 1897. No fue hasta junio de 1899 cuando se publicó ese tema. 50 Idem. Carta, n. ${ }^{\circ}$ 399, fechada en Marchena a 20 de septiembre de 1897.

51 Idem. Carta, n. ${ }^{\circ} 401$, fechada en Marchena a 10 de octubre de ese año. 
tondo donde Azpiazu dibujó el retrato de Juan Misa, un titirimundi y una vista de la feria y un dibujo más amplio donde se muestra en un primer término el exterior de la barraca del polichinela con un gran cartel y un grupo de niños formando cola para entrar. A lo lejos se aprecian varias casetas y gallardetes decorando el real de la feria sevillana ${ }^{52}$.

A finales de octubre de 1897 Gestoso se dirigió a la editorial indicándole que había recibido dos artículos ${ }^{53}$. En noviembre de 1897 el escritor recibió una carta del editor donde le preguntaba si había recibido el dibujo original del pintor García Ramos, un número de la revista y un ejemplar del último folleto publicado. Respecto a lo primero, el pintor sufrió una dolencia que le impedía dibujar, de ahí que la editorial le reclamase los dibujos a Gestoso para terminar su trabajo. También le sugirió que tres de los seis dibujos enviados por Azpiazu no podían ir en la misma crónica, motivo por el que ambos habían valorado hacer otra crónica. Los dibujos se denominaban una capea, un balcón de la plaza un día de toros y en el real de la feria ${ }^{54}$. Y efectivamente, la crónica salió a la semana siguiente bajo el título "Una feria en un pueblo de Andalucía"55. Gestoso contó cómo se celebraba una corrida de toros en cualquier pueblo andaluz en fiestas, si bien los matices que ofrece en su texto hacen pensar que conociese los dibujos que Azpiazu había remitido a la editorial. El ilustrador hizo tres dibujos sacados de tres fotografías que hizo en la Plaza Ducal de la localidad sevillana de Marchen ${ }^{56}$. El primero muestra el graderío de la plaza construido ex profeso para la celebración sobre la fachada de las casas consistoriales donde se colocaba la presidencia de la corrida. De igual forma, se aprecian los balcones de la plaza también poblados de gente para disfrutar de la fiesta. Sobre el albero de la plaza situó al torero y sus ayudantes ${ }^{57}$ (Figs. 3-4). El segundo dibujo mostraba a tres mujeres ataviadas con mantilla blanca y abanicos sobre uno de los balcones de la plaza exornado con un repostero. Es de destacar la posición que muestran, claramente copiada de una fotografía realizada por el $\operatorname{artista}^{58}$ (Figs. 5-6). El tercero volvió a remitir al tema de la feria de ganado y mostró una

52 Vid. La Ilustración Artística. n.o 834. pp. 822-823. El autor cobró 70 pesetas por esta crónica junto con el artículo denominado La cabeza del rey don Pedro y la Entrada de san Fernando en Sevilla, vid. AMDB. FEMS. Contabilidad General. Libro de Diario, n. ${ }^{\circ}$ 9, p. 152

53 Vid. IC. BCC. Fondo Gestoso. Correspondencia. Leg. 1895-1898. Carta n. 404, fechada el 25 de octubre de 1897.

54 Idem. Carta, s/n.o tras la n. ${ }^{\circ}$ 404, fechada en Barcelona el 4 de noviembre de 1897.

55 Vid. La Ilustración Artística, n. ${ }^{\circ}$ 835, de 27 de diciembre de 1897, pp. 838-839.

56 Cfr. RAMOS ALFONSO, R.; RAMOS SUÁREZ, M.A.: op. cit., p. 106

7 Cfr. AMVG. Fondo Azpiazu. AZP-909.

58 Idem. AZP-979.

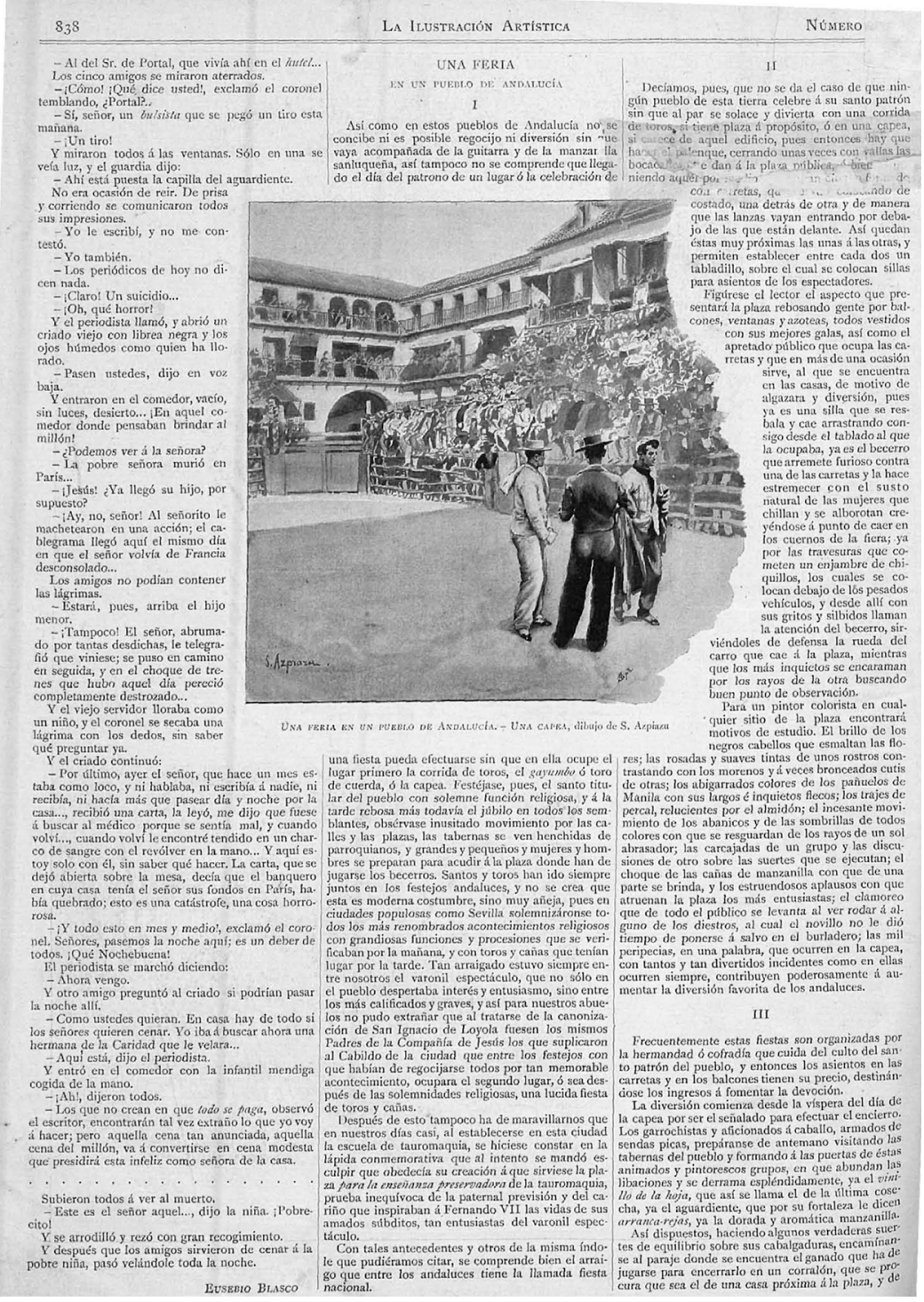

Fig. 3: Una capea en "Una feria en un pueblo de Andalucía", La Ilustración Artística, n.o 835, de 27 de diciembre de 1897, p. 838 


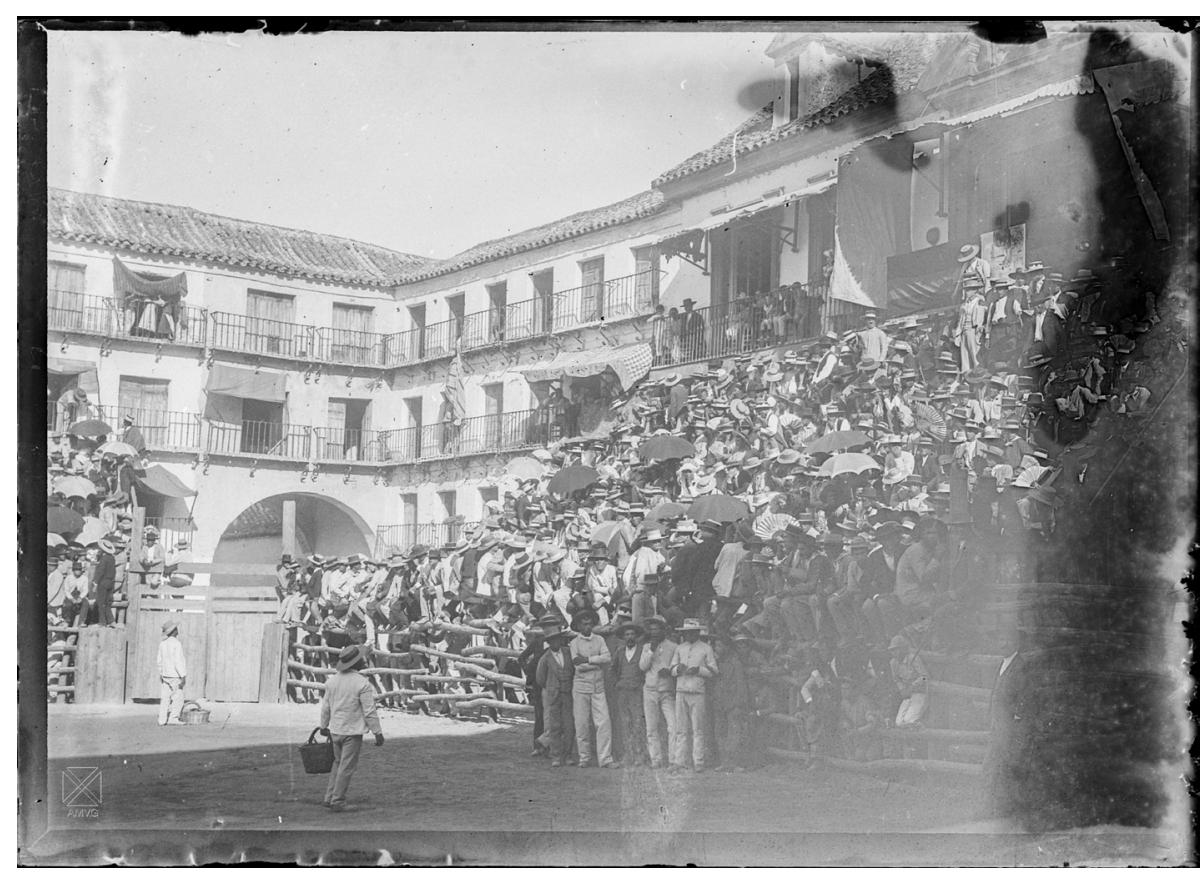

Fig. 4: Vista del graderío montado en la Plaza Ducal de Marchena (Sevilla). AMVG. Fondo Azpiazu. AZP-909

pareja de caballistas junto a una caseta en las que un camarero les ofrece algún vino de la tierra. Un cartel anuncia las bebidas en la caseta, haciendo un guiño a la cartelería con el cambio de una grafía y al fondo de la escena, el dibujante aprovechó otra fotografía y recreó el lugar donde por entonces se celebraba la feria de Marchena, apreciándose la muralla, Torre del Oro y la torre de la iglesia de santa María de la Mota junto a la muchedumbre que se situaba sobre el cerro ${ }^{59}$ (Figs. 7-8).

59 Idem. AZP-979

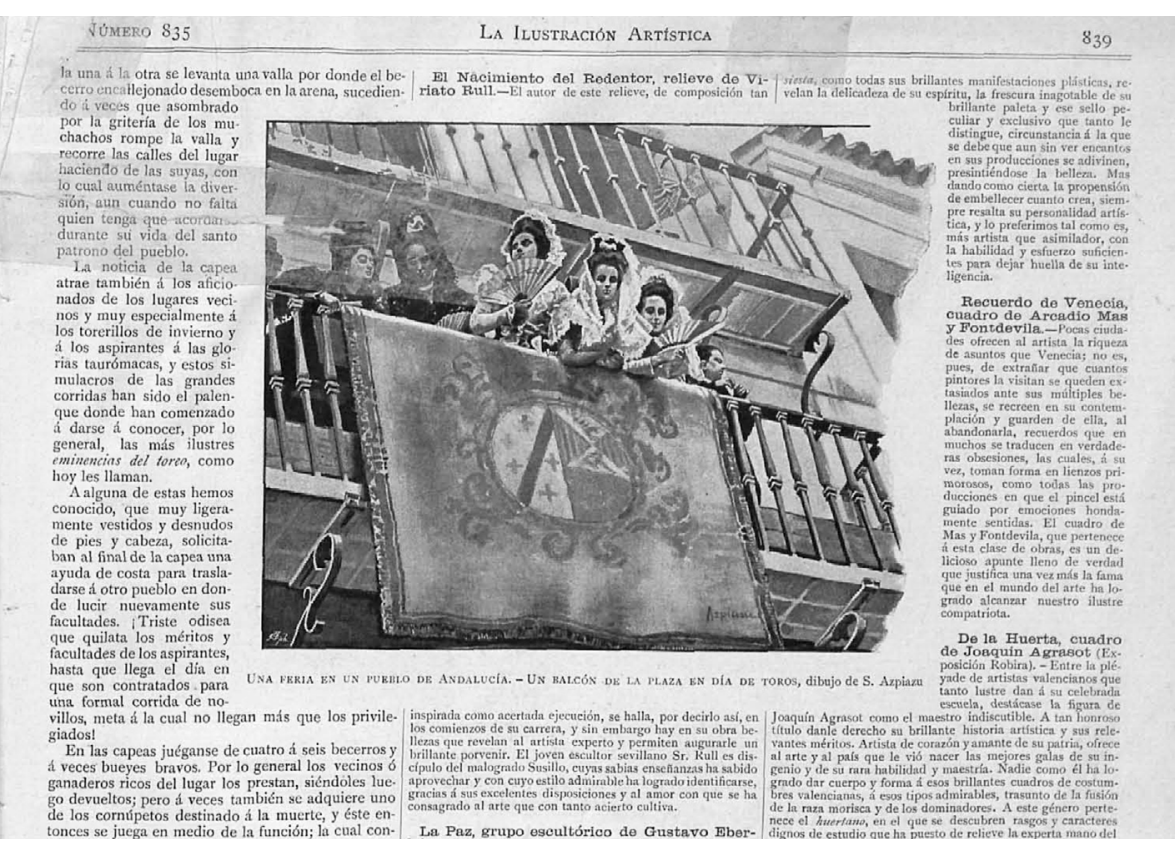

Fig. 5: Un balcón de la plaza en un día de toros en "Una feria en un pueblo de Andalucía" La Ilustración Artística n. ${ }^{\circ} 835$, de 27 de diciembre de 1897. p. 839

Dos meses después, La Ilustración Artística reclamó a Gestoso el artículo Pelando la pava junto a los tres dibujos que formarían parte del mismo ${ }^{60}$. Dos semanas después, Azpiazu respondió a Gestoso cuáles eran los tres temas que acompañarían la crónica. El primero mostraba un patio de un cortijo donde había dos muchachos hablando, el segundo era una reja con una pareja donde al fondo se apreciaba una callejuela con una iglesia y el tercero lo conocido como el "cobro del piso" ${ }^{61}$. La crónica se inició cuestionándose de dónde venía el modismo de pelar la pava, duda que Gestoso consultó a dos amigos y "doctos folkloristas andaluces” Luis Montoto y Rodríguez Marín, para con posterioridad narrar cómo se

60 Vid. IC. BCC. Fondo Gestoso. Correspondencia. Leg. 1895-1898. Carta n. 405, fechada en Barcelona el 22 de diciembre de 1897

61 Idem. Carta, n.o 282, fechada en Marchena a 9 de enero de 1898. 


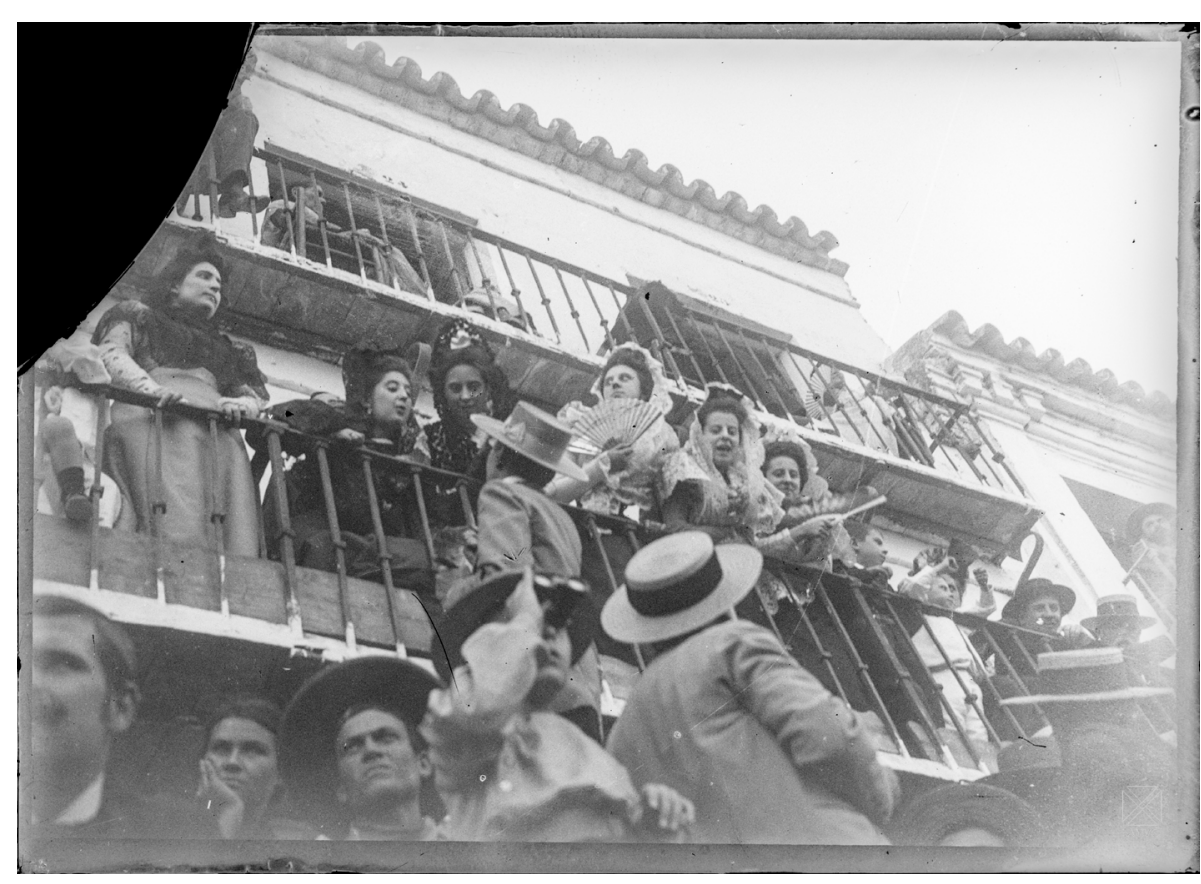

Fig. 6: Vista de los balcones de la Plaza Ducal de Marchena (Sevilla) en un festejo taurino. AMVG. Fondo Azpiazu. AZP-979

mantenía esta tradición. Y así, Azpiazu hizo tres dibujos ${ }^{62}$; el primero mostraba una calle empedrada y estrecha de la localidad de Osuna con grandes ventanas y cierros a la calle y al fondo una espadaña. En primer plano, y junto a una reja, una pareja "pelaba la pava"63. La segunda escena nocturna se titula "cobrando el piso". En ella un grupo de mozos sabiendo que uno rondaba a una chica se divertían con el pidiéndole una cantidad que, de no ser así, jaleaban al novio, hacían ruido, le daban con unos garrotes por detrás, para terminar llamando la atención de la familia de ella y provocar un gran alboroto en la calle. La última

62 Vid. La Ilustración Artística, n. 838, de 17 de enero de 1898, pp. 46-47.

63 Esa imagen apareció en la lámina CXII del libro La Bendita tierra de S. y J. Álvarez Quintero. Curiosamente el texto que los hermanos Álvarez Quintero escribieron para ilustrar la imagen ya hacía referencia al tema del artículo. En él se decía: “¿Una calle de un pueblo andaluz, llena de ventanas todo ello, y en ninguna se ve a un galán pelando la pava? Pero ¿̇a qué hora inverosímil ha tomado el dibujante su apunte?’

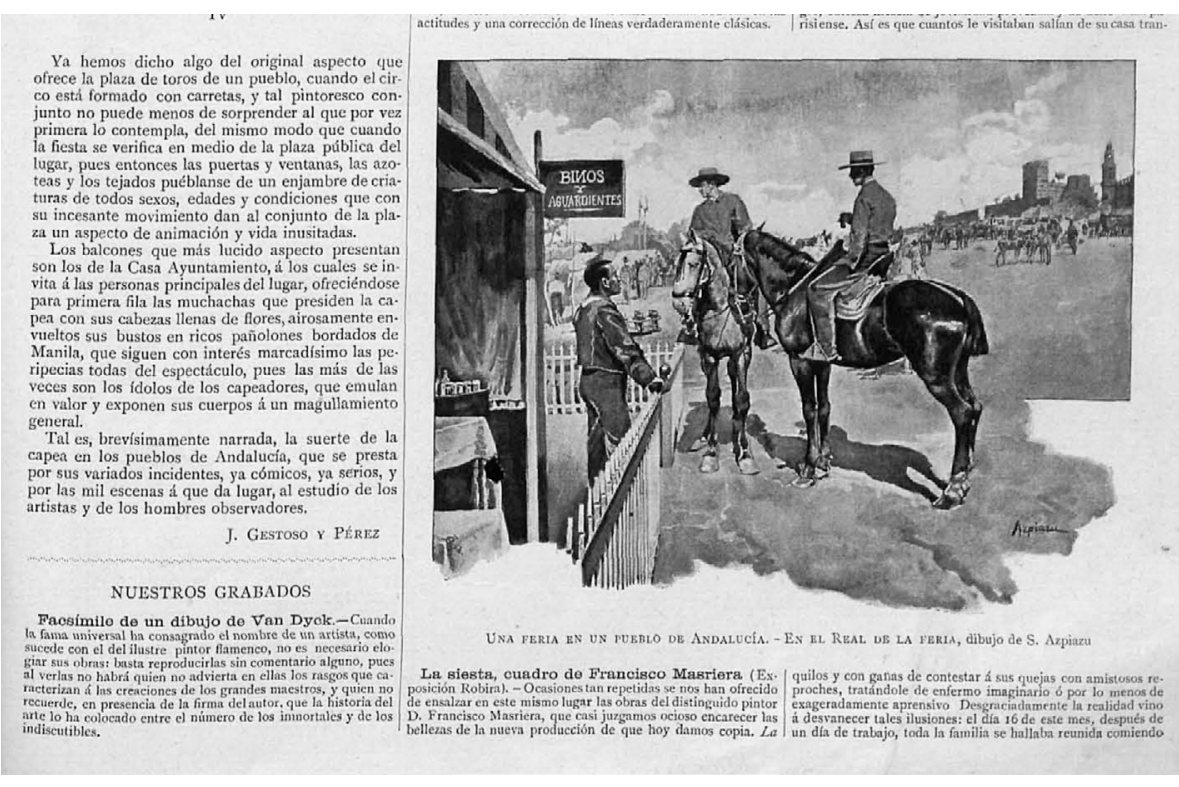

En el Real de la feria en "Una feria en un pueblo de Andalucía", La Ilustración Artística, n.o 835, de 27 de diciembre de 1897. p. 839

ilustración refleja una escena de cortejo en el patio de un cortijo andaluz donde la moza sentada en una silla recibe los halagos del chico sentado sobre una piedra. Al concluir esta serie, Azpiazu cobró 175 pesetas por su realización ${ }^{64}$.

En la carta mencionada anteriormente, el ilustrador indicó a Gestoso que el nuevo tema propuesto de la riña de gallos le parecía conveniente, si bien le solicitaba ideas para su elaboración. Finalmente, le indicó que le devolvía las fotografías de una crónica denominada Cristóbal el bravo, quedando en su poder otra fotografía de gran tamaño donde se mostraba la Romería del Rocío ${ }^{65}$. Por tanto, esto mantiene la teoría que Azpiazu pintaba las ilustraciones de las crónicas siguiendo las instantáneas como modelo.

64 Vid. AMDB. FEMS. Contabilidad General. Libro de Diario, n. ${ }^{\circ}$ 9, p. 214

65 Idem. Carta, n. ${ }^{\circ} 282$, fechada en Marchena a 9 de enero de 1898 


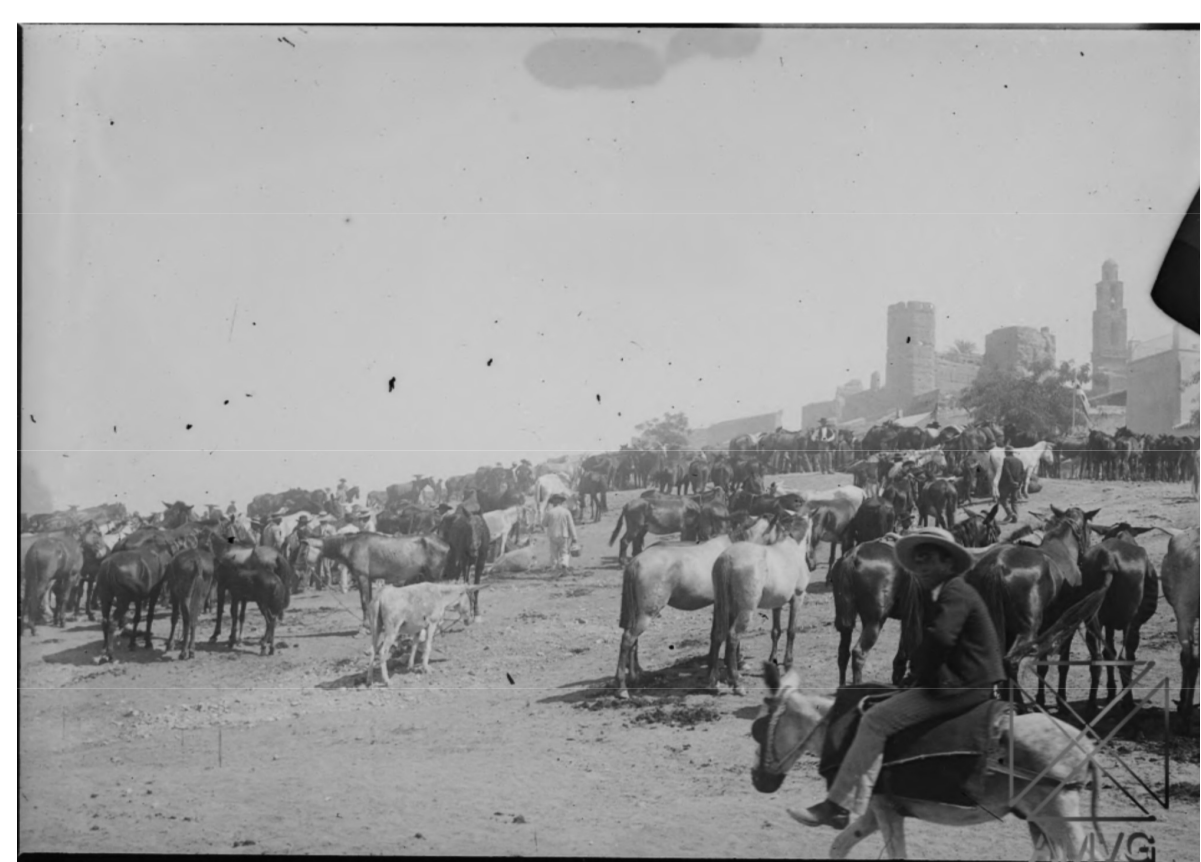

ig. 8: Vista de la Feria de Marchena en los años 1897-1898. AMVG. Fondo Azpiazu. AZP-863

A fines de enero de 1898, Azpiazu comunicó a Gestoso que no podía dibujar las escenas para el artículo de peleas de gallo hasta que no visitase Sevilla y conociese de primera mano esa actividad lúdica. Sin embargo, le propuso otra nueva crónica de la que ya tenía concluidos tres dibujos. Consideraba muy interesante hacer un artículo sobre los "Rosarios de la Aurora”. Azpiazu también le recordó que recibió las fotografías de la romería del

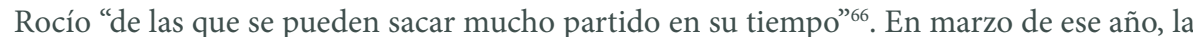
editorial contactó con Gestoso para recordarle un nuevo encargo en el que estaba trabajando con Azpiazu. Se trataba del artículo titulado "Los toreros del Porvenir" G7. Gestoso había elaborado un texto contando la tradición del toreo en Andalucía, nombrando a las grandes

66 Idem. Carta, n. ${ }^{4}$ 408, fechada en Marchena a 30 de enero de 1898

67 Idem. Carta, s/n. . $^{\circ}$ después de la 412 , fechada en Barcelona a 17 de marzo de 1898 figuras del momento y cómo la costumbre despuntaba en algunos pueblos sevillanos, caso de Utrera. Por su parte, Salvador Azpiazu elaboró tres dibujos. El primero mostraba a un aspirante a torero montado en los topes de un vagón de tren para ir a un cortijo de esa localidad. El segundo ofrecía la imagen de tres jóvenes recogiendo la colecta de la corrida con un lienzo o saco abierto al que lanzaban monedas o productos en especie. Curiosamente el ilustrador obtuvo esta imagen preparando a tres "actores" junto a la puerta de un cortijo, gracias a unas fotografías que reproducen la escena y que se han conservado hasta la actualidad ${ }^{68}$. Y el tercero muestra el tipo de un torero de espaldas con su capotillo en la mano izquierda ${ }^{69}$.

Concluyendo el verano de 1898, el editor contactó con Gestoso para solicitarle un artículo, enviarle la revista donde aparecía el artículo del rosario de la Aurora y que Azpiazu le indicase cuáles iban a ser los dibujos para el nuevo artículo titulado la recolección ${ }^{70}$. En septiembre de ese año la editorial remitió a Gestoso los temas de los dibujos que ilustrarían el artículo de la recolección. Estos eran: la trilla a vapor en un cortijo, mujer segadora en la vega de Carmona y una cuadrilla de segadores, sin embargo, y aunque ese artículo propuesto hacía ya más de un año, no se publicó hasta junio de 1899 como se verá más adelante.

En octubre de 1898 y bajo el título "Los Rosarios en Andalucía"71 se concluyó la crónica que meses antes habían estado fraguando. Gestoso narró la costumbre que había en Sevilla y provincia de las hermandades o asociaciones que en procesión iban rezando y cantando el rosario por las calles. En su artículo contó cómo se celebraban estos rosarios callejeros y su organización. Por su parte, el ilustrador nuevamente empleó imágenes que había realizado en la localidad sevillana de Marchena para en algunos casos hacer una adaptación del tema y en otros copiar la imagen de forma literal ${ }^{72}$. En el dibujo de la cabecera del artículo recogió una procesión nocturna formada por una serie de "viejos" en dos filas y al fondo un estandarte y faroles. La imagen fue extraída de una instantánea que hizo en la procesión

68 Cfr. RAMOS ALFONSO, R.; RAMOS SUÁREZ, M.A.: op. cit., pp. 34, 106. Vid. AMVG. Fondo Azpiazu. AZP- 864 a 866. Gracias a estas imágenes se pueden apreciar las distintas posturas que adoptaron los niños para encontrar la más idónea para dibujarla.

69 Vid. La Ilustración Artística, n. ${ }^{\circ} 856$, de 23 de mayo de 1898. pp. 332-333.

70 Idem. Carta, n. 0 406, de 23 de agosto de 1898.

71 Vid. La Ilustración Artística, n. ${ }^{\circ} 878$, de 24 de octubre de 1898, pp. 686-687.

72 Las fotos que sirvieron para ilustrar los dibujos están en AMVG. Fondo Azpiazu. AZP-853 y AZP-854 Cfr. RAMOS ALFONSO, R.; RAMOS SUÁREZ, M.A.: op. cit., p. 105 
de Jesús Nazareno del Viernes Santo por la calle Las Torres de la citada localidad. Azpiazu copió la escena cambiando la luz, los nazarenos por ancianos manteniendo los que portaban los faroles y sustituyendo la imagen del nazareno del estandarte por una imagen mariana bastante difusa. El dibujo central del artículo es un hermano de la Aurora vestido con capa española y portando un gran farol como los que se llevaban en esas procesiones. $\mathrm{Y}$ el dibujo que cierra la crónica es una composición nocturna en la que un grupo de hombres, con faroles en las manos, forman un coro de instrumentos como la guitarra o campanillas y van entonando y cantando los misterios del rosario ${ }^{73}$.

Mientras tanto, Azpiazu no dejaba de colaborar con otros autores ${ }^{74}$. A finales de 1898 y principios de 1899, realizó dos series de dibujos para sendos artículos firmados por Moreno Godino ${ }^{75}$ y Enseñat ${ }^{76}$. Azpiazu y Gestoso realizaron cinco publicaciones para la revista en el año 1899. La primera se efectuó en abril bajo el título "Camaroneros y freidores"77. El escritor narró cómo en Triana junto al antiguo convento de los Remedios se situaba el conocido "puerto camaronero" donde se pescaban estos pequeños crustáceos por jóvenes que se situaban en ese lugar y cómo un buen número de personas iban a las freidurías a degustar los pescados que se freían bajo amplias campanas por freidores y pinches bien ataviados. El ilustrador hizo un dibujo de cabecera donde se mostraba un pequeño embarcadero y algunos barcos en la orilla de Triana, apreciándose la ciudad de Sevilla y edificios destacados como la Torre del Oro o el campanario de la Giralda a lo lejos. Cruzando el río Guadalquivir se observa el puente de Isabel II. El dibujo del artículo recoge una escena nocturna de un puesto o freiduría bajo una especie de soportal del que salen una pareja ataviados a la española con un cartucho de pescado en sus manos. En el interior se pueden apreciar el mostrador del establecimiento con el freidor tras él, así como

73 Esta tradición se mantiene en algunos pueblos, caso de Priego de Córdoba, donde los "auroros" cada sábado del año a las doce de la noche cantan coplas a la Virgen por las calles de la localidad.

74 Idem. Carta, n.o 407, de 29 de octubre de 1898. La carta también comentaba que Gestoso había estado enfermo el mes de octubre.

75 Este artículo se tituló "Tres cogidas" y ofreció tres escenas. La primera mostraba una calle de Madrid con la Puerta de Alcalá al fondo por la que discurrían tres toreros montados en una calesa, la segund era una visión del callejón y graderío lleno de público de la Plaza de la Maestranza de Sevilla y una tercera que parece un encierro de toros precedido de un caballista con garrocha en una calle de Sevilla, concretamente la Calle san Fernando pues se aprecia la reja de la Fábrica de Tabacos, hoy sede de la Universidad hispalense, vid La Ilustración Artística, no 886 de 19 de diciembre de 1898. pp. 819-820.

$76 \mathrm{Fl}$ artículo se denominé "Escens militares en París", véase Ia Ilustración Artística, n. 896, de 27 de febrero de 1899. pp. 143. Azpiazu dibujó un grupo de militares y mujeres parisinas, así como la fachada nocturna del Salón de Marte.

77 Vid. Ilustración Artística, n. ${ }^{\circ}$ 902, de 10 de abril de 1899, pp. 236-237. la enorme campana donde se prepara el pescado ${ }^{78}$. En mayo de ese año elaboraron una crónica sobre "Corrales y cigarreras"79 donde el escritor describió qué eran los corrales en Andalucía, como era la vida en ellos y su disposición y decoración. Como era de suponer, por la correspondencia conservada entre ambos, Gestoso sirvió de guía a Azpiazu en una de sus visitas a la capital hispalense y en este artículo narró literalmente:

"En la Macarena y en Triana, en los Humeros y en San Bernardo existen numerosos corrales de idéntico tipo al que acabamos de bosquejar, y mi compañero el habilísimo artista Salvador Azpiazu, cuyo lápiz ilustra esta crónica, mostróse muy sorprendido la tarde en que, sirviéndole de cicerone, le hice ver algunos de los corrales de Triana, que sin tener el aspecto monumental de los instalados en las casas palacios que fueron de los marqueses de la Algaba, de los condes de Béjar y de los sres. Levantos, ofrecen un aspecto más risueño que aquéllos, si bien menos artísticos y grandiosos".

De ese modo, valoró al artista como habilidoso y sorprendido de estas construcciones andaluzas donde convivían todas las generaciones, tal como lo reflejó el ilustrador colocando en un hermoso patio de vecinos de la ciudad, una joven junto a otra de mayor edad en un primer plano, y otra mujer en el fondo de la escena bajo una gran parra. La escena se completaba con unas macetas cuajadas de flores situadas en la parte derecha de la escena, algunos enseres u objetos, un pilón o lavadero comunitario a continuación y ropa tendida al fondo de corral, ofreciendo ese aspecto vital que tenían los patios y corrales sevillanos del momento. El artista, fiel a la escena, dibujó hasta un azulejo sobre la pared de una de las casas, donde se mostraba un altar como devoción de los vecinos. La segunda temática de las cigarreras quedó reflejada por Gestoso al narrar su modus vivendi, animando el barrio trianero en sus idas y venidas desde la fábrica de tabacos hasta sus casas. Iban vestidas con el atuendo propio de trajes limpios y almidonados de percal o muselina ceñido al cuerpo, envolviendo el torso con pañuelos de seda blanca o mantones con largos flecos y cabezas muy bien penadas con claveles, ranúnculos o alhelíes, levantando el traje por delante y alardeando de enseñar sus pies y sus calzados de zapatos bajos y medias negras o de listas. Todas van con animadas conversaciones en grupos. Y así es como Azpiazu hizo el dibujo, recreando un par de cigarreras avanzando por el puente hacia el barrio de Triana con su vestuario típico ${ }^{80}$

78 El pago efectuado por la editorial al escritor e ilustrador véanse en AMDB. FEMS. Contabilidad General Libro de Diario, n. ${ }^{\circ} 10$, p. 31

79 Vid. La Ilustración Artística, n. ${ }^{9} 908$, de 22 de mayo de 1899. pp. 334-335.

80 Para conocer los pagos, $c f r$. AMDB. FEMS. Contabilidad General. Libro de Diario, n. ${ }^{\circ} 10$, p. 31 
En su tercera colaboración trataron "La Recolección en Andalucía" ${ }^{81}$. Gestoso se dedicó a analizar cómo se realizaba todo el proceso, describiendo cada uno de los personajes que intervienen en el trabajo: manijero, chiquichanca, trillero... narrando la pugna que había entre la forma tradicional de trabajar y las máquinas nuevas usadas en las faenas agrícolas. Por su parte, Azpiazu hizo tres dibujos; el primero ofreció una visión de una cuadrilla de segadores en plena faena, claramente extraída de una foto en la campiña sevillana, bien de los campos de Marchena o de Carmona; el segundo muestra el tipo de una mujer segadora con su ropa y sombrero típicos y una hoz en la mano y el tercero muestra una trilla de vapor situada en un cortijo, ilustración formada a través de una composición de fotografías que él mismo había realizado en la localidad de Marchena ${ }^{83}$. En él se aprecian los carros llenos de mieses en un primer plano, la trilladora mecánica movida por el tractor, el chispero, los carros ya cargados de paja... ${ }^{84}$

En agosto publicaron la crónica "Posadas y mesones" 85 en la que José Gestoso comienza lamentándose del daño producido por la piqueta destructora en palacios, templos o caserones antiguos y como las posadas, mesones, hosterías y ventorrillos han sido sustituidos por hoteles y restaurantes, a la vez que describe cómo era la vida en aquellas posadas y mesones antiguos. Azpiazu hizo un primer dibujo en el que aparecía la denominada Posada del zapatillo, situada en una calle sin salida en la que un mulo con su dueño esperaba en la entrada de la misma, mientras que una mujer, posiblemente la posadera, esperaba en el zaguán. Sobre la puerta lucía el cartel con el nombre del establecimiento. La fachada mostraba dos plantas, en la primera había un gran balcón con macetas de flores y varias jaulas de pájaros colgadas en la pared y en la segunda había otro balcón cerrado, de menores proporciones. El segundo dibujo de mayor tamaño, ofrecía la visión del patio del mesón solado de piedras y cantos rodados en el que un transeúnte enjaezaba su mulo para incorporarle el carro que también dibujó, varias personas conversando en los bancos de piedra que rodeaban el patio y una señora que se asomaba a los balcones corridos de palo que tenía la primera planta del edificio. Una simple visión del mismo servía para hacerse la idea de cómo serían estos lugares para pernoctar.

81 Vid. La Ilustración Artística, n. ${ }^{9}$ 913, de 26 de junio de 1899, pp. 414-415.

82 La foto se encuentra en AMVG. Fondo Azpiazu. AZP-867.

83 Vid. RAMOS ALFONSO, R. RAMOS SUÁREZ, M.A. op. cit. p. 104

84 Para conocer el proceso de forma resumida, Ibid., p. 82.

85 Vid. La Ilustración Artística, n. ${ }^{\circ}$ 920, de 14 de agosto de 1899, pp. 524-526. Ese mes Azpiazu también publicó dos dibujos en la narración "Piadosa mentira" escrita por A. Sánchez Ramón, vid. La Ilustración Artística, n. ${ }^{\circ}$ 919, de 7 de agosto de 1899, pp. 507-508
El último artículo, realizado en septiembre de ese año, recibió el título de "Galleros y gallos"86 Gestoso, tras reivindicar que esta tradición llegó a Andalucía de tierras americanas, narró cómo se preparaban estos animales para la lucha y cómo era la actividad en el reñidero donde se celebraban las luchas, así como los aficionados que asistían. El dibujante hizo tres imágenes para la crónica; la primera era un artístico cartel con dos gallos pintados en una tabla cogida a una base de forja artística y colgada en la puerta del establecimiento; el segundo mostraba un reñidero en plena ebullición donde dos gallos peleaban en un coso cercado, mientras que alrededor un buen grupo de hombres animaban, jaleaban y pujaban por ellos y el tercer dibujo mostraba a varios galleros dirigiéndose al lugar de la pelea.

Aunque por los encargos antes mencionados, Gestoso y Azpiazu debieron mantener comunicaciones durante el año 1899 éstas no han llegado hasta nosotros. La siguiente carta es de diciembre de ese año y en ella el ilustrador informó a Gestoso que había mandado los dibujos de la crónica "Giras de campo" a la editorial. En el primero dibujó una pareja de muchachas bailando sevillanas y el resto de los personajes tocando las palmas y la guitarra formando un círculo. En el segundo dibujó un columpio donde está sentada una joven, y los demás espectadores bailan. También le informó que en breve empezaría los dibujos de artículo "Ventorrillos" donde en el primero pintaría una puerta con una ventana donde jinetes a la andaluza estarán bebiendo y en el otro dibujaría un coche lleno de juerguistas ${ }^{87}$. El encargo se demoró tres meses, pues hasta marzo del año siguiente no entregó esos dibujos al editor barcelonés. Instó al escritor a que enviase sus textos al editor y que le indicase nuevos temas pues conocía mejor las costumbres andaluzas, para ir trabajando en cómo ilustrarlos $^{88}$

En el año 1901 realizaron tres publicaciones en la revista. En la primera bajo el título "Patios y azoteas" ${ }^{\prime 99}$ el escritor va describiendo los distintos patios de Sevilla y su tipología, pasando por los grandes patios de casas nobiliarias y adentrándose también en los más sencillos y modestos. Posteriormente, hace un análisis de las azoteas sevillanas observándolas desde un paraje elevado y apreciando como despuntan la Giralda y los grandes edificios de la ciudad. El ilustrador, por su parte, ofrece dos vistas de la ciudad. La primera, el dibujo

86 Vid. La Ilustración Artística, n.o 925, de 18 de septiembre de 1899, pp. 605-606.

87 Vid. IC BCC. Fondo Gestoso. Correspondencia. Leg 1899-1900. Carta n. 100, en Madrid a 27 de diciembre de 1899 .

88 Idem. Carta, n. 135 , en Santa Cruz de Mudela (Ciudad Real) a 25 de marzo de 1900. Azpiazu se hospedaba en el Hotel Pizarro de esa ciudad.

89 Vid. La Ilustración Artística, n. ${ }^{\circ} 943$, de 22 de enero de 1900, pp. 60, 62. 
de cabecera, desde una azotea donde dos mujeres, una de ellas montada en el pretil de la misma, conversan y observan la ciudad desde esa atalaya. Claramente se aprecia en el fondo de la imagen una vista de la Giralda junto a la catedral de perfil, la iglesia colegial del Salvador y otro templo en el lado izquierdo de la imagen. La segunda ilustración muestra un patio con una escalera con grandes macetas y árboles, imagen típica de un patio de vecinos. La segunda publicación se tituló "Higos chumbos" higos chumbos y la amplia venta que tiene la fruta para ricos y pobres en los puestos que se montan en la ciudad, destacando uno del paseo de la Alameda de Hércules. Azpiazu dibujó una higuera a la orilla de algún camino donde una mujer coge la fruta y un puesto de higos chumbos situados en las plazas y paseos con grandes jarros y cántaras de agua muy fría para consumirla con la fruta. La última publicación de ese año se tituló "Ventas y Ventorillos" Azpiazu hizo un dibujo de cabecera de la crónica donde se apreciaba la entrada a una venta. En un camino que llevaba a Sevilla, con la Giralda en la lejanía, se situaba esta venta a la que acudía la gente a tomar alguna bebida como los caballistas que aparecían en la escena, servidos por un camarero o la gente que se sentaba a la puerta del establecimiento a la sombra de una parra. En el dibujo del interior del artículo, dos parejas se dirigían hacia una venta montadas en un coche de la época.

Para el año 1901 realizaron cinco colaboraciones de forma conjunta. La primera de ellas en marzo se tituló "El florero sevillano" ${ }^{\text {"92 }} \mathrm{o}$ vendedor de flores. Gestoso se dedicó a narrar como era el trabajo de este vendedor que portaba un canasto con todo tipo de flores y que las iba pregonando por la calle. Azpiazu hizo un dibujo de cabecera del artículo mostrando una vista de Sevilla con la Giralda, la catedral al fondo y la muralla del Alcázar en un primer término. Delante de esa vista colocó una vara de un rosal con grandes rosas en él, decorando la vista de la ciudad. El dibujo del artículo mostraba al vendedor con su atuendo típico y delante de una puerta y ante dos muchachas. Una de ellas se coloca una flor en el pelo, recibiendo la aprobación de la que la acompaña. La segunda aportación fue publicada en mayo de 1901 y se tituló "Cruces de mayo" tradición de esta fiesta y cómo se exornaban los patios y corrales de vecinos con un altar y una cruz decorada con flores. Azpiazu hizo dos dibujos, el primero mostraba un patio

90 Vid. La Ilustración Artística, n. ${ }^{\circ}$ 947, de 19 de febrero de 1900, pp. 124, 126.

91 Vid. La Ilustración Artística, n. ${ }^{\circ}$ 981, de 15 de octubre de 1900, pp. 669-670.

22 Vid. La Ilustración Artística, n. ${ }^{\circ}$ 1004, de 25 de marzo de 1901, pp. 206-207.

93 Vid. La Ilustración Artística, n. ${ }^{\circ}$ 1010, de 6 de mayo de 1901, pp. 302-303. con una mesa con un mantel como improvisado altar y sobre él una hornacina en la pared en la que había cruz decorada con jarrones con flores, faroles y cortinas. Delante del altar, un grupo de personas de distintas edades cantaba al ritmo de una guitarra y tocaba las palmas ${ }^{94}$. También la tercera aportación es del mes de mayo y estaba dedicada a "la Romería del Rocío"95. El escritor ahondando en los orígenes de la fiesta, narró la tradición de la hermandad rociera de Triana. Azpiazu dibujó la llegada de una hermandad a la ermita del Rocío en Almonte, ofreciéndose la imagen de la antigua ermita engalanada, a la que se acerca la carreta de un simpecado, hombres a caballo, mujeres andando y otras montadas en las carretas preparadas al efecto. El dibujo del artículo muestra un rociero montado a caballo portando el estandarte de la hermandad. El mes de agosto publicaron el artículo "Campanarios, torres y espadañas" ${ }^{96}$. Gestoso hace una narración histórico-artística de estos espacios, analizándolos arquitectónicamente y Azpiazu dibujo varios ejemplos de torres, espadañas, campanarios e incluso cúpulas de construcciones de la ciudad de Sevilla como la balaustrada de la Casa de Pilatos con su iconografía de las cinco cruces de Jerusalén, las mansardas y cúpula del antiguo convento de San Pablo el Real, hoy parroquia de la Magdalena, la balaustrada y espadaña del antiguo convento de Montesión, la Girald o la espadaña del convento de la Encarnación. "Jiras y columpios"97 es la última publicación de ese año. En ella se narró cómo la gente disfruta de las tardes de invierno o primavera en los patios o corrales, donde cualquier excusa es buena para improvisar un columpio o marcarse unos bailes. Y las dos escenas que recreó el dibujante fueron una pareja jugando con el columpio, mientras que otras conversan sentadas y otra bailan junto a un grupo que canta y toca las palmas.

El año 1902 se inició con una publicación en el mes de marzo. Llevaba el título de "Buñoleros y buñoleras" ${ }^{\prime 98}$ y describieron literaria y pictóricamente cómo se vendía esta masa frita en las distintas ferias y veladas de la capital hispalense. En casetas de feria se situaban estos puestos al que acudían hombres y mujeres a degustarlos, tal como se aprecia en el primer dibujo; en el segundo se observa a las vendedoras alrededor de un perol donde se freían y se ofrecía a los clientes. Ese mismo mes, la redacción de Montaner y Simón avisó a Gestoso que había recibido el texto de "Cantadores y bailadoras", que le habían enviado su artículo

94 Azpiazu cobró por el trabajo de los dibujos mencionados con anterioridad, cfr. AMDB. FEMS. Contabilidad General. Libro de Diario n..$^{\circ}$ 10, p. 323, fechado el 27 de septiembre de 1900

95 Vid. La Ilustración Artística, n. ${ }^{\circ}$ 1.013, de 27 de mayo de 1901, pp. 350-351.

96 Vid. La Ilustración Artística, n. ${ }^{\circ} 1.026$, de 26 de agosto de 1901, pp. 556-557.

97 Vid. La Ilustración Artística, n. ${ }^{\circ}$ 1.038, de 18 de noviembre de 1901, pp. 747-748.

98 Vid. La Ilustración Artística, n. ${ }^{\circ}$ 1.054, de 10 de marzo de 1902, p. 175 
de las gitanas y que iban a maquetar el texto y los dibujos dedicados a las rejas ${ }^{99}$. En abri de ese año, Azpiazu se dirigió a Gestoso indicándole que había mandado a Barcelona los dibujos del artículo "Cantadores y bailadoras". Le consultó si había mandado el artículo de "Las Rejas", y que estaba concluyendo las ilustraciones del denominado "Pescadores de río". Nuevamente le solicitó otros temas como base para otros dibujos y además le expuso que tuvo intención de ir a la feria de Sevilla, pero no pudo por complicaciones que le surgieron ${ }^{100}$ Para julio salió publicado el artículo "Las Rejas"101 donde Gestoso narraba la tradición rejera de Sevilla tanto en balcones como en ventanas, la importancia de los rejeros a lo largo de los siglos y los ejemplos más significativos sobre todo en los palacios de los nobles sevillanos. Una de ellas es la que dibujó fielmente Azpiazu para abrir el artículo, situada concretamente en la Casa de Pilatos. El otro dibujo era una reja artística de una ventana donde una pareja pelaba la pava. En septiembre de ese año se publicó la crónica "Cantadores y bailadoras"102 tradición de todos los pueblos andaluces donde despuntan algunos nombres en cada época, caso de la mencionada Manuela la de Triana. Los dibujos son escenas de un baile improvisado sobre una mesa acompañado del toque de la guitarra y las palmas y donde un grupo anima y jalea a un mozalbete para que cante alguno de los palos flamencos ${ }^{103}$.

Durante los años 1902 a 1907 continuó la relación profesional entre Azpiazu y Gestoso, aunque no se ha conservado correspondencia entre ambos ${ }^{104}$. No obstante, también siguieron trabajando conjuntamente y por separado. De Gestoso únicamente se conoce un trabajo titulado "La gitana andaluza"105 no ilustrado por Azpiazu, sino por García Ramos. Sin embargo, Azpiazu ilustró varios artículos sin contar con los textos del mencionado escritor. El primero fue la novela titulada "El filón" contada en tres números de la revista e ilustrada por un dibujo de cabecera de Azpiazu ${ }^{106}$. El segundo narró el cuento de antaño "Juan el Bueno" y fue escrito por F. Moreno Godino ${ }^{107}$. El dibujo de cabecera refleja la

99 Vid. IC. BCC. Fondo Gestoso. Correspondencia. Leg. 1901-1902. Carta n. 296, fechada en Barcelona 19 de marzo de 1902

00 Idem. Carta, n. ${ }^{\circ} 214$, fechada en Madrid a 30 de abril de 1902

101 Vid. La Ilustración Artística, n. ${ }^{\circ}$ 1.071, de 7 de julio de 1902, p. 447

102 Vid. La Ilustración Artística, n. ${ }^{\circ} 1.080$, de 8 de septiembre de 1902, p. 589.

103 Cfr. AMDB. FEMS. Contabilidad General. Libro de Diario n. ${ }^{\circ} 11$, p. 55.

104 Tras seguir consultando el fondo Gestoso en su sección de correspondencia no ha aparecido ningun carta más entre ambos.

105 Vid. La Ilustración Artística, n. ${ }^{\circ}$ 1.051, de 17 de febrero de 1902, pp. 125-126. Se conoce el pago al escritor, vid. AMDB. FEMS. Contabilidad General. Libro de Diario n. ${ }^{\circ} 13$, p. 65.

106 Vid. La Ilustración Artística, n. ${ }^{\circ}$ 1.072, 1.073 y 1.074 del mes de julio de 1902.

107 La mujer que narraba la historia recibió ese nombre porque "vivía más allá del patio", vid. La Ilustración lucha de dos contra uno en un prado con castaños alrededor y el dibujo del interior del artículo muestra un caballero con lanza, escudo y casco montado a caballo con quien se encontraron Juan y la princesa, tal como narra el cuento ${ }^{108}$. "La Ultrapatiana" redactada por Antonio de Valvuena ${ }^{109}$ en la que Azpiazu realizó dos dibujos. El primero ofrece la imagen de una calle madrileña en la que se muestran las puertas y escaparates de establecimientos y donde un hombre con bastón parece seguir a una madre e hija caminando unidas del brazo, volviendo ésta última la mirada al señor. El segundo presenta a una mujer con velo arrodillada en un reclinatorio leyendo una pequeña novena en el interior de un templo del que se muestra una gran columna, una reja renacentista al fondo y una gran lámpara de aceite que cuelga del techo de la iglesia ${ }^{110}$

Dos fueron las aportaciones individuales de Azpiazu a la revista en el año 1904. En prime lugar, el dibujo de cabecera del texto "El alma en pena" del escritor Moreno Godino en el que el artista recrea una escena nocturna mostrando a Juanito Lumbreras sorprendido por el alarido que narra la historia ${ }^{111}$. La segunda aportación también fue un dibujo de cabecera del artículo "Entre dos cimas" del escritor Menéndez Agusty ${ }^{112}$. El ilustrador dibujó dos personajes sobre una cima donde uno de ellos señala a un pueblo situado en la ladera de otra cima, pareciendo más una pintura realizada a óleo que un dibujo ${ }^{113}$. Otra de las colaboraciones fue un dibujo a página completa que a su vez incluía cinco ilustraciones sobre el viaje que hizo el presidente de la república francesa M. Loubet a Madrid, siendo recibido por el rey Alfonso XIII y las autoridades españolas. En ellas muestra una revista o parada militar, una corrida de toros presidida por el rey, la decoración exterior que mostraba el ayuntamiento madrileño y la Puerta del Sol iluminada de noche y dos escudos acolados. La crónica se completaba con varias fotografías de lo acontecido ${ }^{114}$. De febrero de 1906 es la última colaboración individual del dibujante. El artículo firmado por M. Martínez

Artística, n. ${ }^{\circ} 1076$, de 11 de agosto de 1902, pp. 523-526. Véanse los pagos en AMDB. FEMS. Contabilidad General. Libro de Diario n. ${ }^{\circ} 11$, p. 313.

08 Cfr. AMDB. FEMS. Contabilidad General. Libro de Diario n. ${ }^{\circ} 11$, p. 553

109 Vid. La Ilustración Artística, n. ${ }^{\circ}$ 1094, de 15 de diciembre de 1902.

110 Cfr. AMDB. FEMS. Contabilidad General. Libro de Diario n. ${ }^{\circ} 11$, p. 553

111 Vid. La Ilustración Artística, n. ${ }^{\circ}$ 1.164, de 18 de abril de 1904, pp. 267-268. El pago por el dibujo está anotado en AMDB. FEMS. Contabilidad General. Libro de Diario n. ${ }^{\circ}$ 12, p. 291.

112 Vid. La Ilustración Artística, n. ${ }^{\circ}$ 1.166, de 2 de mayo de 1904, pp. 299-300.

113 El pago de 160 pesetas por ese y otros dibujos se recoge en AMDB. FEMS. Contabilidad General. Libro de Diario, n. ${ }^{\circ} 12$, p. 291

114 Vid. La Ilustración Artística, n. ${ }^{\circ}$ 1245, de 6 de noviembre de 1905, p. 721. El pago fue de 75 pesetas, $c f r$. AMDB. FEMS. Contabilidad General. Libro de Diario, n. ${ }^{\circ} 12$, p. 545 
Barrionuevo recibió el nombre de "La condesa de la Buenagua"115 y se ilustró con un dibujo de cabecera con una escena de la orilla del río Guadalquivir donde hay un castillo rodeado de vegetación y palmeras a las afueras de Sevilla que se observa en la lejanía ${ }^{116}$.

Los trabajos realizados de forma conjunta vuelven a aparecer en febrero de 1903 donde publican una crónica denominada "Pescadores de río"117. Gestoso describió la vida de estos pescadores formados en el río, siguiendo la tradición familiar ${ }^{118}$. Azpiazu, por su parte, dibujó una vista de estos vendedores en el puente de Triana, apreciándose al fondo la ciudad de Sevilla con la catedral y la Giralda, otras edificaciones y barcos con sus velas en la parte derecha de la imagen. El dibujo interior del artículo reflejaba el tipo de un vendedor de camarones con su cesta en el brazo ${ }^{119}$

Posteriormente, en el primer número de la revista del año 1904 ambos elaboran un artículo titulado "Vendedores ambulantes"120 donde se trata la venta de pan de Alcalá de Guadaira y pescado entre otros. Azpiazu hizo solo un dibujo donde reflejó un vendedor de marisco con su cesta por una calle ${ }^{121}$. Se desconoce qué pudo suceder a la hora de ilustrar esta crónica, pues las anteriores habían sido ilustradas con dos o tres dibujos del artista. Sin embargo, en un número posterior de la revista, concretamente en la revista del día 6 de febrero del año siguiente apareció un dibujo en el que se mostraba un vendedor de pan de la localidad sevillana de Alcalá de Guadaira tal como narraba Gestoso al principio de su artículo. Un panadero de esa localidad vestido con blusa de crudillo y sombrero de ala ancha con su robusto mulo con sus angarillas forradas y cargadas de pan ofrecía el producto a una señora asomada a la puerta de su casa ${ }^{122}$. En abril de ese año trabajaron en una crónica sobre "El Gazpacho"123. Gestoso se remontó a buscar los orígenes del gazpacho y sus recetas más antiguas, así como a contar que son los trabajadores del campo quienes consumen esa sopa fría. Por su parte, Azpiazu realizó dos dibujos, uno que ocupaba el inicio del texto donde varios segadores con sus cucharas y situados en el mismo tajo acuden a tomarlo y otro

115 Vid. La Ilustración Artística, n. ${ }^{\circ}$ 1261, de 26 de febrero de 1906.

116 Por el dibujo cobró 50 pesetas, cfr. AMDB. FEMS. Contabilidad General. Libro de Diario n. ${ }^{\circ} 12$, p. 545

117 Vid. La Ilustración Artística, n. ${ }^{\circ} 1101$, de 2 de febrero de 1903, pp. 94-95.

118 Cfr. AMDB. FEMS. Contabilidad General. Libro de Diario, n. ${ }^{\circ} 11$, p. 281.

119 Cfr. AMDB. FEMS. Contabilidad General Libro de Diario, no $11, \mathrm{p} .553$

120 fid A Ilustración Artítica, p. 553.

121 Cfr. AMDB. FEMS. Contabilidad General. Libro de Diario, n. ${ }^{\circ} 11$, p. 553

122 Vid. La Ilustración Artística, n. ${ }^{\circ} 1206$, de 6 de febrero de 1905, p. 15.

123 Vid. La Ilustración Artística, n. ${ }^{\circ} 1163$, de 11 de abril de 1904, pp. 251-252. donde un campesino está majando los ingredientes para hacerlo junto a varias vasijas de barro $^{124}$. Las imágenes guardan relación con las mostradas en el artículo de "La recolección", que a su vez fueron extraídas de fotos como se mencionó con anterioridad.

En mayo, realizaron un artículo sobre las "Aceitunas y los aceituneros"125. Gestoso hablaba de las costumbres de la cogida de la aceituna en la campiña sevillana y algunos pueblos de Córdoba, su uso e incluso la vestimenta de cada uno de los cogedores y cogedoras en los cortijos y molinos. El ilustrador hizo dos dibujos, el mayor recogía un aceitunero vareando un olivo para extraer la aceituna mientras que una mujer recogía el fruto caído en un lienzo tal como se hace actualmente. Al fondo de la escena otra mujer agachada recoge las aceitunas y un carro espera el transporte de las mismas. En el segundo dibujo se muestra dos mujeres portando su atuendo típico para el desempeño de esta labor ${ }^{126}$. En una revista de octubre presentaron un nuevo trabajo sobre las "ermitas y santuarios" andaluces ${ }^{127}$. Bajo el título "Poniendo en marcha la comitiva entre los cánticos del pueblo" Azpiazu recreó una escena de romería en la que bajando un cerro y viéndose a lo lejos una ermita, los romeros con pañuelos blancos sobre la cabeza portan unas andas con un templete tapado donde se guardaba una imagen de la Virgen, a la que también acompañan mujeres y niños. Varios de ellos portaban faroles y una cruz o manga al inicio de la procesión. La escena se completa con otros romeros montados en carretas o a caballo. Años antes, la imagen fue recogida por Salvador Azpiazu en una fotografía donde se reflejaba la romería de la Virgen de Setefilla de Lora del Río (Sevilla), sirviendo de modelo al ilustrador ${ }^{128}$ (Figs. 9-10). La segunda ilustración, más pequeña, muestra el cerro y santuario de la Virgen de la Cuesta. Gestoso reflejó la importancia y devoción a la Virgen, narrando la mencionada romería de la patrona de Setefilla ${ }^{129}$.

124 El pago por estos dibujos se recoge en AMDB. FEMS. Contabilidad General. Libro de Diario, n. ${ }^{\circ}$ 12, 291.

125 Vid. La Ilustración Artística, n. ${ }^{\circ} 1169$, de 23 de mayo de 1904, pp. 347-348.

126 Para conocer el pago por los dibujos, cfr. AMDB. FEMS. Contabilidad General. Libro de Diario, n. ${ }^{\circ} 11$ p. 553.

127 Vid. La Ilustración Artística, n. ${ }^{\circ} 1190$, de 17 de octubre de 1904, pp. 686-687.

128 Vid. AMVG. Fondo Azpiazu. AZP-924. Esta fotografía junto con otras de Salvador Azpiazu fue publicadas para narrar la romería de Setefilla, vid. GONZÁLEZ CARBALLO, I: GÓMEZ SÁNCHEZ, I.; GAMERO NIETO, M.: Testimonios de una devoción eterna. Fotografías de Lora del Río en el Fondo Azpiazu. Lora del Río, Asociación Espacio y Tiempo de Lora, 2015. p. 150.

129 Los dibujos fueron abonados a Azpiazu, $c f r$. AMDB. FEMS. Contabilidad General. Libro de Diario, n. 12 , p. 291 


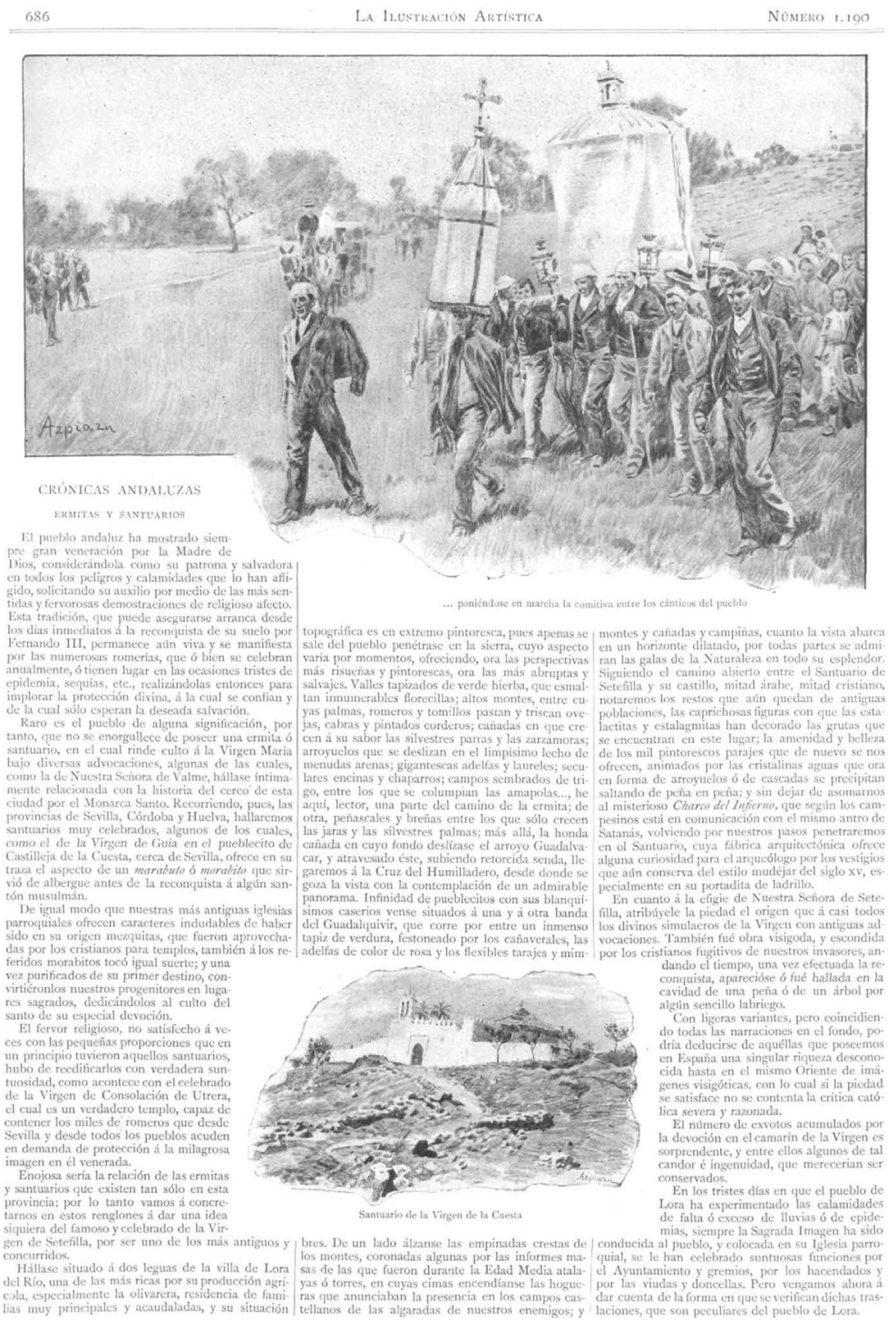

Fig. 9: En "Ermitas y santuarios", La Ilustración Artística, n.o 1.190, de 17 de octubre de 1904. p. 686

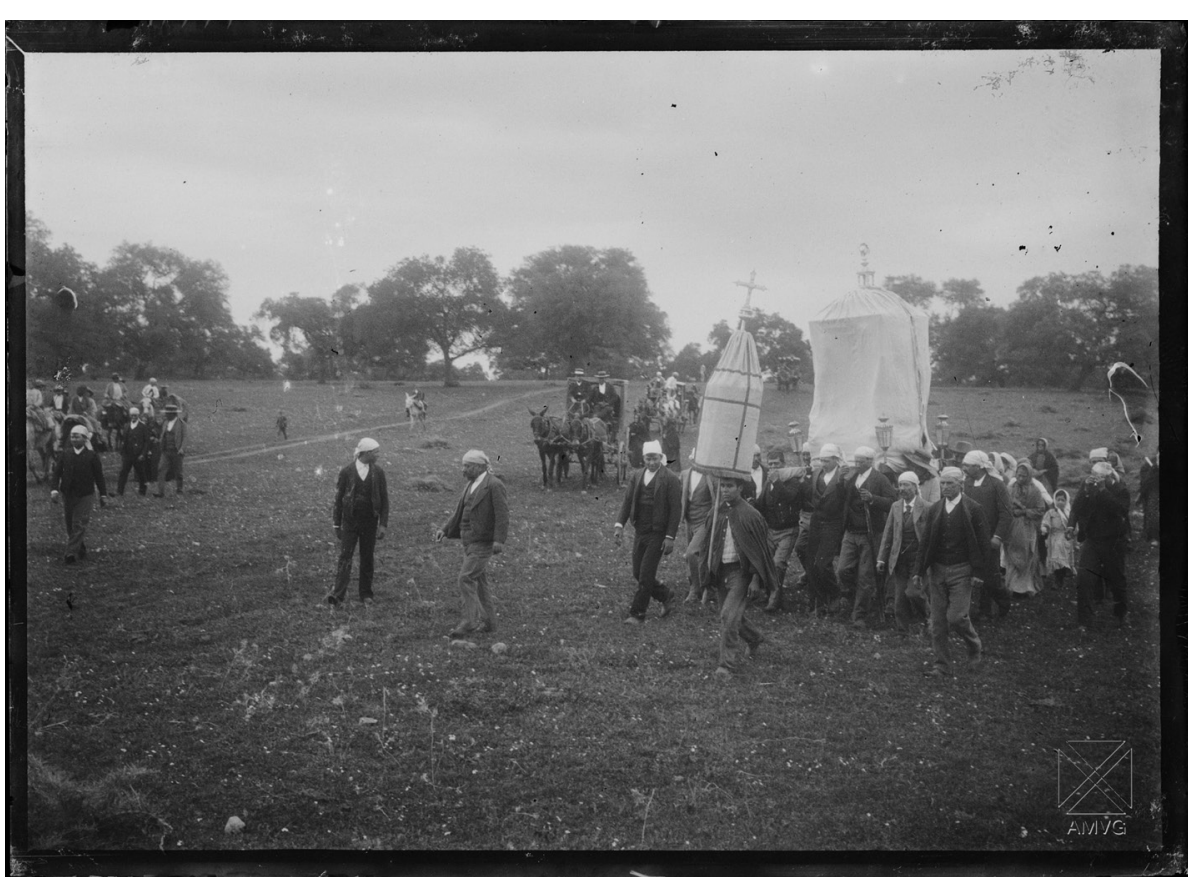

Fig. 10: Fotografía de la Romería de Setefilla en Lora del Río (Sevilla). AMVG. Fondo Azpiazu. AZP-924

Una única colaboración se materializó entre ambos en la revista mencionada en el año 1905. Hicieron un artículo con el título "Gitanos y gitanas"130. Gestoso narró cómo vivían los gitanos en el barrio de la Cava de Triana, dificultades para conocerlos su trabajo en la forja, la forma de vida, etc. que poco tienen que ver con los dibujos que ofreció el pintor para la crónica. Por entonces, Azpiazu estaba lejos de Sevilla ${ }^{131}$, y no se documentó para dibujar ese mundo de los gitanos y realizó dos dibujos empleando aquellas imágenes que tenía de Sevilla y su feria. El primero situado en la cabecera mostraba en un primer plano, a la derecha de la imagen, a una mujer de tez oscura con un moño en el pelo y unas flores

130 Vid. La Ilustración Artística, n. ${ }^{\circ}$ 1.212, de 20 de marzo de 1905, pp. 187-188.

131 Azpiazu por aquellas fechas se encontraba en Tarragona, vid. RAMOS ALFONSO, R.; RAMOS SUÁREZ, M. A.: op. cit., p. 18. 
y envuelta en un mantón de cuadros. La figura se situaba en un paisaje que recordaba a la feria del ganado sevillana donde tratantes de ganados vendían sus animales y al fondo se apreciaban casetas y gallardetes que adornaban el real. Y el segundo dibujo, de menor tamaño, mostraba un grupo en el interior de una caseta donde un hombre tocaba la guitarra y otras mujeres estaban conversando y en ademán de bailar ${ }^{132}$.

Las últimas colaboraciones registradas en esa revista son del año 1907. La primera salió en el mes de marzo bajo el título "Jardines andaluces"133. Gestoso va narrando y describiendo los jardines del Alcázar de Sevilla, sus antecedentes musulmanes, los distintos tipos de vegetación, sus construcciones, los baños, los juegos de agua... y los relaciona con los jardines renacentistas ya transformados como el palacio de los duques de Alcalá en su Casa de Pilatos, el de los Medina Sidonia en Sanlúcar de Barrameda, los que poseyó el duque de Arcos en su arruinado palacio de Marchena... para posteriormente compararlos con los sencillos jardines de casas de vecinos donde conviven los arriates y cangilones alrededo del brocal del pozo ${ }^{134}$. Por su parte, Azpiazu muestra una imagen de los jardines del Alcázar de Sevilla donde dos mujeres aparecen a la derecha de la ilustración en un primer plano. La primera mira desafiante al espectador y la segunda hace lo mismo abanicándose. Estas imágenes han sido extraídas de unas fotografías realizadas años antes. Se seleccionó ese motivo de las mismas, se dibujaron tal cual y se situaron en ese entorno de los jardines del palacio sevillano ${ }^{135}$. El jardín mostrado con sus frondosos árboles y paseos delimitados con rotondas y fuentes muestra una construcción al fondo que recuerda al cenador de Carlos V del mencionado palacio. El segundo dibujo titulado de forma sugerente "El jardín del pobre" muestra cómo una mujer con una regadera en su mano derecha y su mano izquierda apoyada en la cintura está regando unas macetas cuajadas de flores en un patio o corral cubierto por una vela o lona que daba sombra y aliviaba la canícula veraniega ${ }^{136}$.
La última colaboración se efectuó en la revista de junio de 1907 y trataron el tema de las "Cruces y humilladeros"137. Gestoso analizó las cruces y su situación como recuerdo de algo sucedido narrando alguno de ellos o justificando su colocación como devoción colectiva pidiendo alguna oración a los transeúntes. Además, narró lo que sucedía en torno a estos humilladeros junto a ventas para divertirse ${ }^{138}$. Por su parte, el artista presentó un dibujo de cabecera donde en torno al templete sevillano de la Cruz del campo, todos los domingos una muchedumbre paseaba, otros hombres con sombreros de ala ancha observaban como unas jóvenes bailaban sevillanas, otros miraban, paseaban o cantaban o incluso iban montadas en coches de caballos alejándose de la escena. El segundo dibujo mostraba una cruz de humilladero rodeada de vegetación y enmarcada por las murallas del Alcázar sevillano ${ }^{139}$.

En definitiva, se presentan las distintas aportaciones del escritor sevillano José Gestoso y del ilustrador vasco Salvador Azpiazu en la revista La Ilustración Artística. Trabajos que formaron parte de la serie "Costumbres Populares" donde la unión del texto y las ilustraciones se complementan a la perfección, tanto por el escritor como conocedor de esas tradiciones y costumbres sevillanas y andaluzas, como por el dibujante que utilizaba sus fotografías como buen fotodocumentalista, reflejando la realidad social, cultural y tradicional de finales del siglo XIX y principios del XX. Los temas tratados eran propuestos a la editorial Montaner y Simón de forma conjunta, unas veces por uno otras por otro como se deduce de la correspondencia conservada por Gestoso, que a su vez nos ofrece relaciones y vivencias personales y profesionales entre ambos.
132 Azpiazu cobró 50 pesetas el día 30 de enero de ese año, cfr. AMDB. FEMS. Contabilidad General. Libro de Diario, n..$^{\circ} 12$, p. 296

133 Vid. La Ilustración Artística, n. 1.314, de 4 de marzo de 1907.

134 A Gestoso se le pagaron 30 pesetas por su trabajo, cfr. AMDB. FEMS. Contabilidad General. Libro de Diario, n. ${ }^{\circ} 13$, p. 339

135 Véase imagen en AMVG. Fondo Azpiazu. AZP-887.

136 Azpiazu cobró 50 pesetas por ambos dibujos, $c f r$. AMDB. FEMS. Contabilidad General. Libro de Diario, n. ${ }^{\circ} 13$, p. 207.
137 Vid. La Ilustración Artística, n.o 1.329, de 17 de junio de 1907.

38 Cfr. AMDB. FEMS. Contabilidad General. Libro de Diario, n. ${ }^{\circ} 13$, p. 339

139 Azpiazu cobró 50 pesetas por esos dibujos. Cfr. AMDB. FEMS. Contabilidad General. Libro de Diario n. ${ }^{\circ} 13$, p. 207 


\section{BIBLIOGRAFÍA}

ÁLVAREZ QUINTERO, S. y J.: La Bendita Tierra. Madrid, Voluntad, 1927.

"Archivo Municipal de Vitoria-Gasteiz. Sección de Fotografía: Fondo Azpiazu. París: Fin de siglo", Colección Photo-album Bilduma, n. ${ }^{\circ}$ 11. Zarautz, Photomuseum, 1997.

CASQUETE DE PRADO SAGRERA, N.: José Gestoso y Sevilla. Biografía de una pasión. Sevilla, Ayuntamiento, 2016.

FONTBONA, F.: “La ilustración gráfica. Las técnicas fotomecánicas” en El Grabado en España. (Siglos XIX y XX) Summa Artis. Vol. XXXI. Madrid, Espasa Calpe, 2000, pp. 429-441.

GONZÁLEZ CARBALLO, J.; GOMEZ SÁNCHEZ, I.; GAMERO NIETO, M.: Testimonios de una devoción eterna. Fotografías de Lora del Río en el Fondo Azpiazu. Lora del Río, Asociación Espacio y Tiempo de Lora, 2015.

GONZÁLEZ DE ASPURU, S.: Salvador de Azpiazu. Itinerarios y figuras de un artista alavés. [Exposición] Álava, Museo de Bellas Artes, 2005.

RAMOS ALFONSO, R.; RAMOS SUÁREZ, M. A.: Azpiazu y Marchena. Imágenes de una villa entre siglos. Marchena, Ayuntamiento, 2017.

VIVES CASAS, F.: La Academia de Bellas Artes de Vitoria (1818-1889). Vitoria, Ayuntamiento, 2000.

VVAA.: "París: Fin de Siglo. Salvador Azpiazu”, Revista digital Photo Berriak, n. 2. Zarautz, Photomuseum, 2010, pp. 5-45. 